\title{
SOIL HYDRAULIC AND PHYSICAL PROPERTIES AS AFFECTED BY LOGGING MANAGEMENT
}

A Thesis presented to the Faculty of the Graduate School

University of Missouri

In Partial Fulfillment

Of the Requirements for the Degree

Master of Science

by

LANGSTON A. SIMMONS

Dr. Stephen H. Anderson, Thesis Supervisor

MAY 2014 
The undersigned, appointed by the Dean of the Graduate School, have examined the thesis entitled

\section{SOIL HYDRAULIC AND PHYSICAL PROPERTIES AS AFFECTED BY LOGGING MANAGEMENT}

presented by

\section{Langston A. Simmons}

a candidate for the degree of

\section{Master of Science}

and hereby certify that in their opinion it is worthy of acceptance.

Dr. Stephen H. Anderson (Chair)

Dr. Frieda Eivazi

Dr. John Kabrick 


\section{ACKNOWLEDGEMENTS}

I share my sincere gratitude to Dr. Stephen H. Anderson for offering me the opportunity to study soil science, and for his patient advisement throughout my graduate

program. I give thanks to the other graduate committee members, Drs. Frieda Eivazi and John Kabrick, for serving on the committee and reviewing the thesis. Very special thanks goes to the late Dr. Felix Ponder for his inspiration and initial guidance to me and his service on the committee.

I am grateful for the assistance the George Washington Carver Fellowship and Thurgood Marshall Scholarship offered me so that I could fulfill my graduate study goals. I also thank the United States Department of Agriculture, Forest Service, for offering me a leave from my work and a flexible work schedule, which made this graduate study possible. I also thank the US Forest Service for allowing me the opportunity to conduct my research in the Middle River II project area timber stands at Callaway County, Missouri. I express additional appreciation to Dr. Stephen Anderson for sharing his laboratory and field expertise which at times were flexible around my work schedule.

Finally, thank you to my mother and father for their supportive acts during my graduate studies. 


\section{TABLE OF CONTENTS}

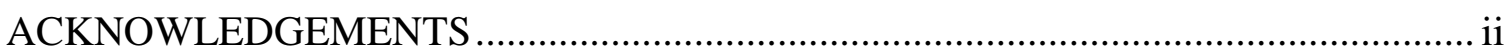

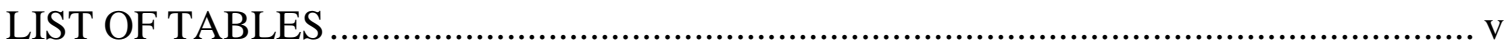

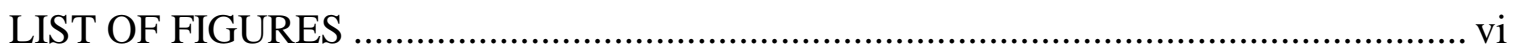

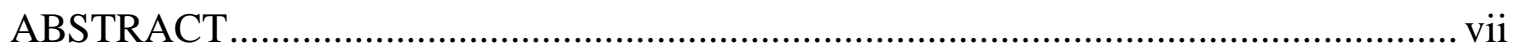

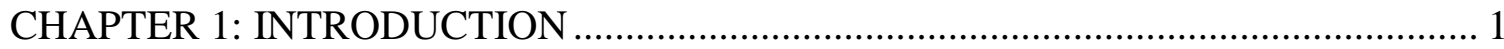

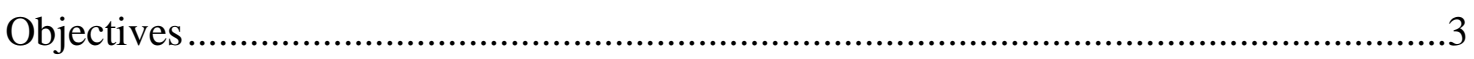

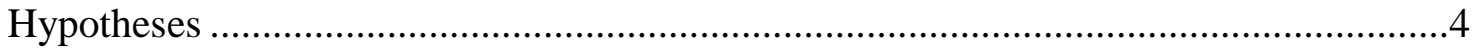

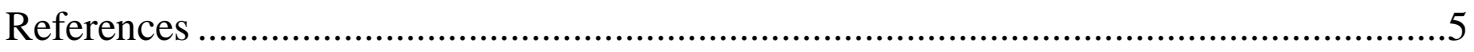

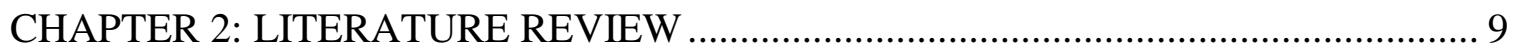

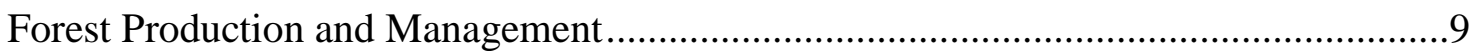

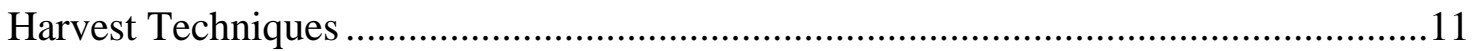

Effects of Forest Harvesting on Soil Physical and Hydraulic Properties........................12

Bulk Density and Soil Strength ............................................................................ 13

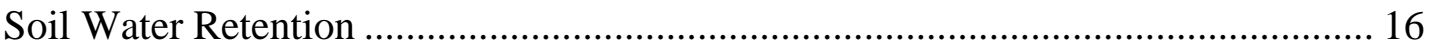

Saturated Hydraulic Conductivity ...................................................................... 17

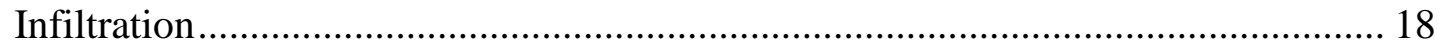

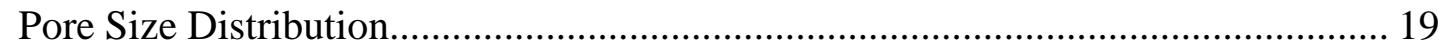

Management for Improving Harvested Areas ........................................................... 21

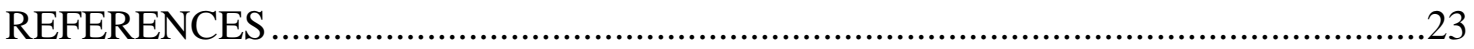

CHAPTER 3: SOIL HYDRAULIC PROPERTIES AFFECTED BY LOGGING

ACTIVITIES IN A CENTRAL HARDWOOD FOREST ………………...................... 33

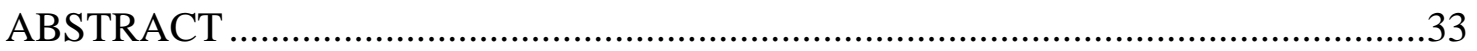




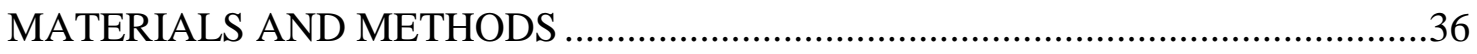

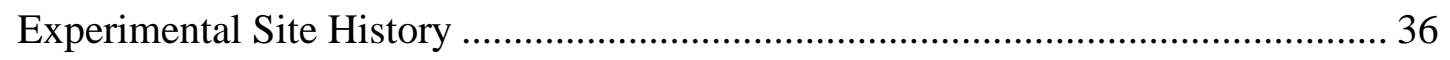

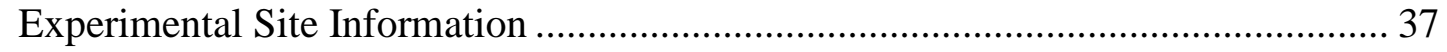

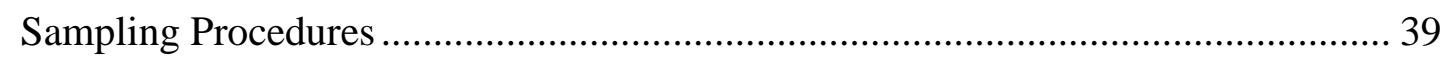

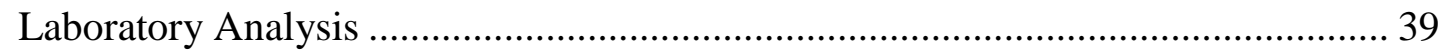

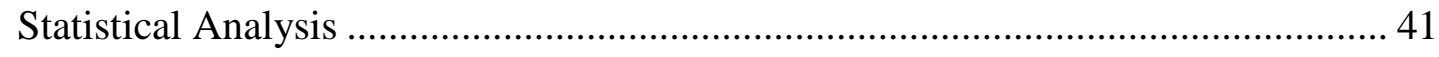

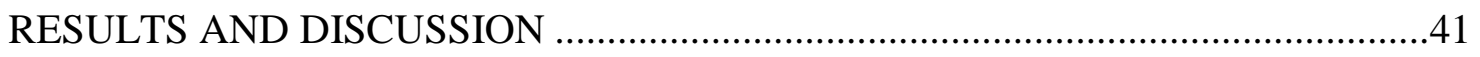

Soil Water Retention ............................................................................ 41

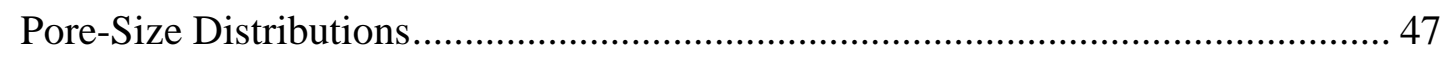

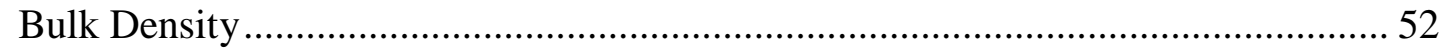

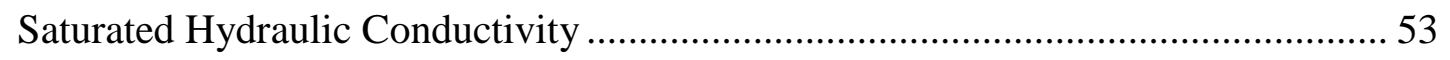

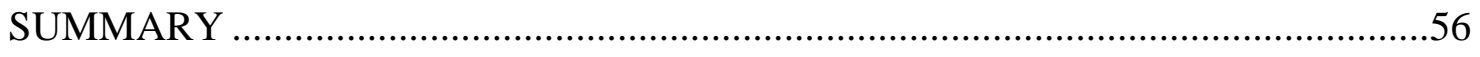

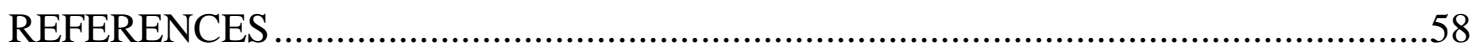

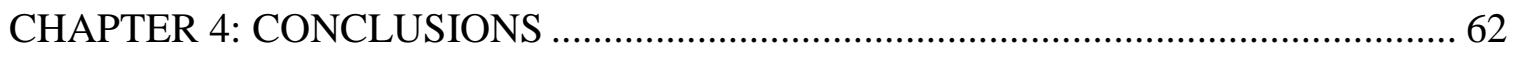

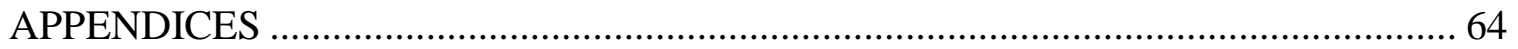

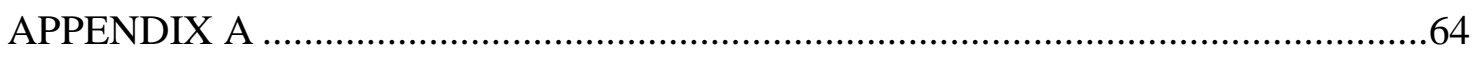

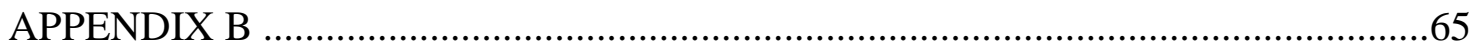

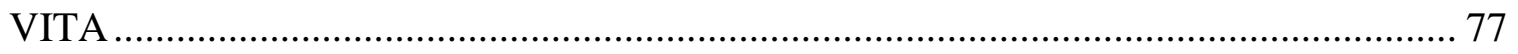




\section{LIST OF TABLES}

$\underline{\text { Table }}$

$\underline{\text { Page }}$

3.1. Soil physical and chemical properties for the study location (Keswick silt loam) ( 5 to $9 \%$ slope) presented by profile horizon with standard deviations indicated in parentheses

3.2. Water retention as a function of soil water pressure $(0.0$ to $-1500 \mathrm{kPa})$ as affected by buffer treatments and soil depth

3.3. Total pores, macropores, coarse mesopores, fine mesopores, and micropores as affected by logging treatments and soil depth.

3.4. Means of $\mathrm{K}_{\text {Sat }}$ and arithmetic means of bulk density as affected by buffer treatments and soil depth 


\section{LIST OF FIGURES}

Figure

3.1. Effects of logging treatments on soil water retention at depths of A) 0 to $10 \mathrm{~cm}$, B) 10 to $20 \mathrm{~cm}$, C) 20 to $30 \mathrm{~cm}$, and D) 30 to $40 \mathrm{~cm}$. Bars indicate LSD (0.05) values and are presented at pressures when significant differences occurred among treatments.

3.1. (cont.). Effects of logging treatments on soil water retention at depths of A) 0 to $10 \mathrm{~cm}, \mathrm{~B}) 10$ to $20 \mathrm{~cm}$, C) 20 to $30 \mathrm{~cm}$, and D) 30 to $40 \mathrm{~cm}$. Bars indicate LSD $(0.05)$ values and are presented at pressures when significant differences occurred among treatments

3.2. Effects of logging treatments and soil depth on pore-size classes of A) macropores (>1000 $\mu \mathrm{m}$ diam.), B) coarse mesopores (60-1000 $\mu \mathrm{m}$ diam.), C) fine mesopores (10 to $60 \mu \mathrm{m}$ diam.), and D) micropores ( $<10 \mu \mathrm{m}$ diam.). Bars indicate LSD (0.05) values and are presented for pore-size classes with significant differences among treatments

3.2. (cont.). Effects of logging treatments and soil depth on pore-size classes of A) macropores (>1000 $\mu \mathrm{m}$ diam.), B) coarse mesopores (60-1000 $\mu \mathrm{m}$ diam.), C) fine mesopores (10 to $60 \mu \mathrm{m}$ diam.), and $\mathrm{D}$ ) micropores ( $<10 \mu \mathrm{m}$ diam.). Bars indicate LSD (0.05) values and are presented for pore-size classes with significant differences among treatments

3.3. Effects of logging treatments and soil depth on A) bulk density and B) saturated hydraulic conductivity $\left(\mathrm{K}_{\mathrm{Sat}}\right)$. The bar indicates the $\operatorname{LSD}(0.05)$ value for bulk density (A) and the LSD (0.05) value for $\mathrm{K}_{\text {Sat }}$ is listed on the graph (B) due to the log scale 


\title{
SOIL HYDRAULIC AND PHYSICAL PROPERTIES AS AFFECTED BY LOGGING MANAGEMENT
}

\author{
Langston A. Simmons \\ Dr. Stephen H. Anderson, Thesis Supervisor
}

\begin{abstract}
Former studies have shown that once compacted, forest soils often recover slowly (many decades) to pre-disturbed levels for soil properties such as bulk density or penetrometer resistance. Runoff and soil erosion from forest lands increases due to effects from this soil compaction. Increased carbon sequestration is expected from forest land; however, increased runoff and erosion will negatively affect carbon sequestration in the soil. As climate change occurs, more intense rain may fall which will create challenges with runoff and erosion from compacted sites. This study was conducted to evaluate the effects of selected harvesting techniques on soil physical and hydraulic properties.

The effects of logging roads, log landing areas, and logged areas on water retention, saturated hydraulic conductivity $\left(\mathrm{K}_{\mathrm{Sat}}\right)$, and bulk density were investigated on harvested sites within the Mark Twain National Forest in Callaway County, Missouri, USA on a moderately well-drained Keswick soil (fine, smectitic, mesic Aquertic Chromic Hapludalfs). Soil cores $(7.6 \mathrm{~cm}$ by $7.6 \mathrm{~cm})$ were removed in four $10-\mathrm{cm}$ depth increments in June and were evaluated for saturated hydraulic conductivity, soil water retention, poresize distributions, and bulk density. Saturated hydraulic conductivity was measured for each core sample using a constant head permeameter, or the falling head method for samples with low values. For the water retention measurements, soil cores were saturated and water retention measurements were recorded for $0.0,-0.4,-1.0,-2.5,-5.0,-10.0$ and -
\end{abstract}


$20.0 \mathrm{kPa}$ readings. Soil aggregate samples were used for the -33 and $-100 \mathrm{kPa}$ water retention readings and samples passed through a $2.0 \mathrm{~mm}$ sieve was used for the $-1,500 \mathrm{kPa}$ water retention reading. The soil bulk density was also determined for the soil core samples. Pore size distributions were estimated using the water retention data from each sample.

Bulk density was significantly higher $(\mathrm{P}<0.01)$ for the logging road and log landing areas compared to the logged areas. This was attributed to the higher levels of soil compaction in the more trafficked areas of the site. Significant interactions $(\mathrm{P}<0.01)$ between treatments and soil depth occurred; logged areas increased with soil depth while the logging road and log landing areas remained fairly constant with depth. No statistical differences in bulk density were observed at the deepest sampling depth (30 to $40 \mathrm{~cm})$. Saturated hydraulic conductivity was also significantly lower $(\mathrm{P}<0.01)$ for the logging road and log landing areas compared to the logged areas. These values were also affected by soil compaction. Values for $\mathrm{K}_{\text {Sat }}$ in the surface soil were 33 times greater for the logged areas compared to the logging road and log landing areas. No statistical differences in $\mathrm{K}_{\text {Sat }}$ values among treatments occurred at the deepest sampling depth (30 to $40 \mathrm{~cm})$.

For the 0 and $-0.4 \mathrm{kPa}$ soil water pressures, water retention was $11 \%$ higher and $7 \%$ higher for the logged areas versus logging road and log landing areas averaged across all soil depths, respectively. Soil water retention was significantly affected $(\mathrm{P}<0.01)$ by soil depth for all pressures; soil water retention increased with increasing soil depth due to increases in clay content. In addition, significant interactions with soil water retention occurred among treatments and soil depth; retention decreased more with depth for logged areas compared to log landing and logging road treatments. For the macropores $(>1000$ 
micrometer diameter) and coarse mesopores (60 to 1000 micrometer diameter) combined, values were $95 \%$ higher for the logged areas compared to logging road and log landing areas within the 0 to $10 \mathrm{~cm}$ depth. Pores decreased with soil depth for coarse mesopores and fine mesopores (10 to 60 micrometer diameter), but increased with depth for the micropores $(<10$ micrometer diameter), The water retention and porosity values were affected by increasing soil bulk density due to differences in soil compaction.

Soil hydraulic properties which included soil hydraulic conductivity, water retention and pore size distributions were significantly affected by forest harvesting treatments. From this study, the methods used in logged areas appear to have caused less change in soil physical and hydraulic properties; however, significant changes occurred with these properties for logging roads and the log landing area. Efforts to reduce compaction should be concentrated in areas of logging roads and log landing areas. 


\section{CHAPTER 1}

\section{INTRODUCTION}

Globally, each year over 11 million ha of tropical forests are destroyed. Another 6 million ha are degraded to desert-like conditions because of economic imbalances and poor land ethic (Powers et al., 1990). A multi-nation report on global trends strongly recommended that we reassess our land use policies to meet the challenges of sustainable development (Brundtland, 1987). As the population of the world continues to grow, the demand for forest products will similarly continue to increase. Soil is a fundamental resource that controls the quantity and quality of such renewable forest resources as timber, wildlife habitat, forage, and water yield; and because soil is a non-renewable resource directly affected by forest management practices it needs to be conserved (Tiarks et al., 1997). Commercial thinning of overstocked stands can reduce fuel for forest fires and provide wood products. Tree harvest necessitates a decision about the most appropriate combination of equipment to fell, to process, and to yard logs or whole trees to roadside for transport. Equipment choice is often based on extraction costs, damage to residual trees, and the extent and severity of soil disturbance (Landsberg, 2003).

Increased forest management and concern over changes in soil productivity are among the topics debated by forest managers and the public (Page-Dumroese, 2006). A key element in this debate is the use of mechanized equipment to extract timber products and the subsequent soil compaction and recovery times (Greacen and Sands, 1980; Froehlich and McNabb, 1984; Jansson and Johansson, 1998; Landsberg et al., 2003; Miller et al., 2004). A potential consequence of severe soil compaction is the significant loss of site productivity (Powers, 1991; Morris and Miller, 1994). Ultimately, the degree of 
compaction caused by harvesting or site preparation affects soil properties (e.g., texture, organic matter, and water content) at the time of disturbance (Block and VanRees, 2002).

Various studies have shown that once compacted, forest soils often recover slowly (many decades) to undisturbed levels of bulk density or soil strength (Sands et al., 1979; Froehlich et al., 1985; Tiarks and Haywood, 1996). Recovery rates are dependent on many factors, but chief among them are number of repeated harvest cycles, soil moisture conditions during harvest, soil texture, and rock-fragment content (Miller et al., 1996; Williamson and Neilsen, 2000; Liechty et al., 2002). The extent of compaction, initial bulk density, depth of impact, and subsequent soil recovery are all factors that determine the consequences of timber harvesting or site preparation on productivity (Page-Dumroese, 2006). In addition, duration and variability of compaction can be significant from site to site or at depth in the soil profile (Beckett and Webster, 1971; Blythe and Macleod, 1978; Courtin et al., 1983). For instance, variability within soil textural groups, forest stands, or on skid trails can be as great as or greater than the variability between them (Courtin et al., 1983). This study proposes to evaluate the effects of selected harvesting techniques on soil physical and hydraulic properties.

Challenges with compaction occur from traffic and heavy loads when soils have insufficient strength to support these loads (Siegel-Issem et al., 2005). When soils fail, which is an increase in density due to the excess load, the bulk density of the soil increases which gives the soil sufficient strength to support the load (Hillel, 1998). Ultimately, the degree of compaction caused by harvesting or site preparation is affected by soil properties (e.g., texture, organic matter, and water content) at the time of disturbance (Block and VanRees, 2002). Moisture content is one of the most important factors influencing the 
compactiblity of soils (Soane, 1990). Higher soil water content reduces soil strength allowing greater increases in density during wet conditions (Jansson and Johansson, 1998). Wet conditions cause the soil to exhibit less strength.

Soil hydraulic properties are very sensitive to compaction (Blanco-Canqui et al., 2004). Jannson and Johansson (1998) found that saturated hydraulic conductivity decreased at the $10 \mathrm{~cm}$ depth by two orders of magnitude due to wheel traffic. In forested settings, compaction not only decreases production but enhances runoff and erosion and negatively affects water quality (Elliot et al., 1998). Thus, management is critical to maintain good hydraulic properties to minimize runoff, erosion, and water quality.

The mass of the equipment used during harvest activities plays a significant role in determining the depth to which soil physical parameters are altered. The depth to which compaction occurs is also dependent upon the soil water content (Hillel, 1998). A practical recommendation is to minimize traffic in order to affect the soil as little as possible (Jansson and Johansson, 1998).

Maintaining optimal soil hydraulic properties in forest managed sites is critical for environmental conservation. Although the effects of timber harvest on bulk density have been studied considerably, not many studies have been conducted on harvest activities' effects on hydraulic properties in soils.

\section{Objectives}

This study is to evaluate forest harvesting treatments on soil physical and hydraulic properties. The treatments include historic logged areas, recent logged areas, logging roads, and log landings. The specific objectives of the experiment are: 
-Evaluate the effects of harvesting treatments on soil bulk density and saturated hydraulic conductivity.

-Assess harvesting treatment effects on soil water retention and pore size distributions.

\section{Hypotheses}

Specific null hypotheses include:

-Soil bulk density is not influenced by forest harvesting treatments.

-Saturated hydraulic conductivity is not affected by harvesting treatments.

-Water retention at selected soil water pressures is not influenced harvesting treatments.

Pore size distributions (macroporosity, mesoporosity, and microporosity) are not affected by harvesting treatments. 


\section{References}

Beckett, P.H., and Webster, R. 1971. Soil variability: A review. Soils and Fertilizers. 34: $1-15$.

Blanco-Canqui, H., Gantzer, C. J., Anderson, S. H., Alberts, E. E., \& Thompson, A. L. (2004). Grass Barrier and Vegetative Filter Strip Effectiveness in Reducing Runoff, Sediment, Nitrogen, and Phosphorus Loss. Soil Science Society of America Journal. doi:10.2136/sssaj2004.1670

Blythe, P.H.T., and Macleod, D.C. 1978. The significance of soil variability for forest soil studies in northwest Scotland. J. Soil Sci. 29: 419-430.

Block, M.D., and VanRees K.C.J. 2002. Mechanical site preparation impacts on soil properties and vegetation communities in the Northwest Territories. Can. J. For. Res. 32: 1381-1392. Brundtland, G. H. (1987). in Our Common Future: [Report of the] World Commission on Environment and Development.

Courtin, P., Feller, M.C., and Klinka, K. 1983. Lateral variability in some properties of disturbed forest soils in southwestern British Columbia. Can. J. Soil. Sci. 63: 529539.

Elliot, W.J., Page-Dumroese, D.S., and Robichaud, P.R. 1998. The effect of forest management on erosion and soil productivity. In Soil Quality and Erosion. Edited by R. Lal. St. Lucie Press, Boca Raton, Fla. pp. 195-209.

Froehlich, H. A., \& Mcnabb, D. H. (1984). Minimizing soil compaction in Pacific Northwest forests. 
Froehlich, H.A., Miles, D.W.R., and Robbins, R.W. 1985. Soil bulk density recovery on compacted skid trails in central Idaho. Soil Sci. Soc. Am. J. 49: 1015-1017.

Greacen, E., \& Sands, R. (1980). Compaction of forest soils. A review. Australian Journal of Soil Research.

Hillel, D., Warrick, A. W., Baker, R. S., \& Rosenzweig, C. (1998). Environmental soil physics. San Diego, CA: Academic Press.

Jansson, K. J., and J. Johansson. "Soil Changes after Traffic with a Tracked and a Wheeled Forest Machine: a Case Study on a Silt Loam in Sweden." Forestry 71, no. 1 (1998): 57-66.

Landsberg, Johanna D., Richard E. Miller, Harry W. Anderson, and Jeffrey S. Tepp. "Bulk Density and Soil Resistance to Penetration as Affected by Commercial Thinning in Northeastern Washington," 2003. http://citeseerx.ist.psu.edu/viewdoc/download?doi=10.1.1.124.120\&rep=rep1\&type= pdf.

Liechty, H.O., Shelton, M.G., Luckow, K.R., and Turton, D.J. 2002. Impacts of shortleaf pine-hardwood forest management on soils in the Ouachita Highlands: a review. South. J. Appl. For. 26: 43-51.

Miller, Richard E, Stephen R Colbert, and Larry A Morris. Effects of Heavy Equipment on Physical Properties of Soils and on Long-term Productivity: a Review of Literature and Current Research. NCASI, 2004.

Miller, R.E., Scott, W., and Hazard, J.W. 1996. Soil compaction and conifer growth after tractor yarding at three coastal Washington locations. Can. J. For. Res. 26: 225-236. 
Morris, L.A., and Miller, R.E. 1994. Evidence for long-term productivity changes as provided by field trials. In Impacts of forest harvesting on long-term site productivity. Edited by W.J. Dyck, D.W. Cole, and N.B. Cornerford. Chapman and Hall, London. pp. 41-80.

Page-Dumroese, Deborah S, Martin F Jurgensen, Allan E Tiarks, Felix Ponder, Jr., Felipe G Sanchez, Robert L Fleming, J Marty Kranabetter, et al. "Soil Physical Property Changes at the North American Long-Term Soil Productivity Study Sites: 1 And 5 Years after Compaction." Canadian Journal of Forest Research 36, no. 3 (March 2006): 551-564. doi:10.1139/x05-273.

Powers, R.F. 1991. Are we maintaining the productivity of forest lands? Establishing guidelines through a network of long-term studies. In Proceedings: Management and Productivity of Western-Montane Forest Soils, 10-12 April 1990, Boise, Idaho. Compiled by A.E. Harvey, L.F. Neuenschwander, and I.D. Boise. USDA For. Serv. Gen. Tech. Rep. INT-GTR-280. pp. 70-89.

Powers, R.F., Alban, D.H., Miller, R.E., Tiarks, A.E., Wells, C.G., Avers, P.E., Cline, R.G., Fitzgerald, R.O., and Loftus, N.S., Jr. 1990. Sustaining site productivity in North American forests: problems and prospects. In Sustained Productivity of Forest Soils: Proceedings of the 7th North American Forest Soils Conference, Vancouver, B.C., August 1988. Edited by S.P. Gessel, D.S. Lacate, G.F. Weetman, and R.F. Powers. The University of British Columbia, Vancouver, B.C. pp. 49-79. Sands, R., Greacen, E.L., and Gerard, C.J. 1979. Compaction of sandy soils in radiata pine forests: I. A penetrometer study. Aust. J. Soil Res. 17: 101-113. 
Siegel-Issem, C.M.; J. A. Burger; R. F. Powers; F. Ponder; and S. C. Patterson. 2005. Seedling Root Growth as a Function of Soil Density and Water Content. Soil Science Society of America Journal. 69: 215-226.

Soane, B. (1990). The role of organic matter in soil compactibility: A review of some practical aspects. Soil \& Tillage Research. doi:10.1016/0167-1987(90)90029-D

Tiarks, Allan E., Marilyn A. Buford, Robert F. Powers, Jerry F. Ragus, Deborah S. PageDumroese, Felix Ponder Jr, and Douglas M. Stone. "North American Long-term Soil Productivity Research Program.” In Communicating the Role of Silviculture in Managing the National Forests: Proceedings of the National Silviculture Workshop, 140-147, 1997. http://www.nrs.fs.fed.us/pubs/gtr/gtr_ne238/gtr_ne238_140.pdf.

Tiarks, A.E., and Haywood, J.D. 1996. Effects of site preparation and fertilization on growth of slash pine over two rotations. Soil Sci. Soc. Am. J. 60: 1654-1663.

Williamson, J.R.; and W. A. Neilsen. 2000. The influence of forest site on rate and extent of soil compaction and profile disturbance of skid trails during ground-based harvesting. Can. J. For. Res. 30: 1196-1205. 


\section{CHAPTER 2}

\section{LITERATURE REVIEW}

\section{Forest Production and Management}

Forest productivity is a general term referring to growth and maintenance of all or any part of the assemblage of plants and animals that exist in forests at scales that range from microplots to entire ecosystems. In contrast, site productivity more narrowly refers to the growth or capacity of a site to grow trees at the scale of individual forest stands (Morris and Miller, 1994). Forest productivity can be also defined as the yield of commercially valuable timber products per unit of land over time. In a basic sense, the forest management process is the input of practices to achieve a certain kind, amount, and rate of product and service output (Burger, 2009). However, this definition is more sensitive to market conditions than site conditions; a more suitable description includes the future productivity of the forest. Often times the economic benefit of protecting the soil resources is not evident (Powers et al., 1990). Traditional economic analyses weight the worth of soil protection in terms of expected future revenues from timber harvests, and ignore the fact that site quality may decline and that yields may fall. For example, the standard Faustmann method for computing soil expectation values and economically optimal rotations commonly assumes that soil productivity holds constant or increases, but never declines (Routledge, 1987). One method to gain timely insight into long-term sustainability is to measure soil physical properties prior to and following harvest activities. Resultant values can be indicators of detrimental impacts to future forest productivity (Butnor et al., 2006). With an 
understanding of the effect of harvesting activities on soil properties, prolonging the soil's long-term productivity may be realized (Tiarks et al., 1997).

Thinning timber stands allows forests to produce more commercially valuable product per unit of land in a shorter period of time (Powers et al., 1990). Regenerated forests left to their own means take a much longer period to reach capacity, and even then, many non-native and invasive species may dominate if left unchecked (Westbrooks, 1998). Through research, an optimal balance between maximum production capacity and minimum disturbance to the long-term productivity of the forest is desired (Powers et al., 1990).

Research has shown that timber production capacity declines on non-wetland sites are related principally to site organic matter losses and soil porosity reductions (Powers et al., 1990). Soil compaction, churning, rutting, mixing, displacement, and removal are types of disturbance that can reduce tree root growth through their influence on soil physical properties (Miller et al., 2004). Compacted soils will eventually return to their natural state, but the length of time required depends on the depth of compaction, presence and depth of freezing and thawing cycles, and presence of expanding clays (Tiarks et al., 1997). Direct correlations of compaction impacts on forest plant growth are frequently unclear because compaction is often associated with other detrimental disturbances, such as soil displacement, mixing, and rutting (Page-Dumroese et al., 2006). In addition, plant growth on compacted areas (skid trails, landings, etc.) has sometimes been found to be greater than on non-impacted soil because of reduced weed competition (Miller et al., 1989; Miller and Anderson, 2002). During a 12-year economic valuation study, Kiran and Kaur (2011) showed that forest soil restoration activities by the Forest Department resulted in economic 
benefits post-restoration compared to economic losses pre-restoration. Establishment of soil quality monitoring variables that are practical to use, give meaningful information over a wide range of sites, and provide a benchmark for evaluating soil change, is essential. In order to make accurate projections of future site productivity losses or gains following various soil disturbances, adequate baseline assessments must be made of important sitespecific properties such as bulk density, forest floor depth, soil cover, etc. (Page-Dumroese et al., 2000). During these projections, taking soil degradation into account will have a major impact on the identification of lands on which timber production is determined not to be economical (Routledge, 1987).

\section{Harvest Techniques}

An uneven-aged timber management approach was applied in the study location. As stands of shade-intolerant trees such as oak species grow older, openings in the canopy due to natural or man-made disturbances increase the availability of light and other resources (Larsen et al., 1999). These gaps in the stand allow established seedlings, especially those which have developed large root systems over several years, to experience rapid shoot growth (Johnson, 1979; Dey et al., 1996).

Forest harvesting methods have a significant effect on the land resource. The amount of total soil disturbance varies considerably between different yarding techniques. Megahan (1980) determined that aerial and skyline cable techniques are far less damaging than other yarding techniques. Sidle (1980) presented data showing that tractors cause the greatest amount of soil disturbance (35 percent of land area) and soil compaction (26 percent of land area). Miller and Sirois (1986) compared the land area disturbed by cable, 
skyline, and groundskidding systems; they found groundskidding operations to affect 31 percent of the total land area, whereas cable yarding only affected 16 percent of the total land area. Similarly, Patric (1980) found skidders to serve the smallest area per mile of road (20 acres), with skyline yarding serving the largest area per mile of road (80 acres).

The proportion of area that is disturbed by constructed roads varies widely due to differences in topography, road specifications, and logging equipment (Megahan, 1988). As a result, summaries or central tendencies of reported data only provide a very general indication of the area that may be disturbed by harvest activities. Such summaries include those by Froehlich (1977) of 1.5 to $24 \%$ of the harvest area disturbed by roads, with an average "approaching 8\%"; those by Megahan (1988) of 1 to 30\% of the area disturbed by roads and an added 1 to $10 \%$ of the disturbance occurring in log landings, with an average total of about $10 \%$ for tractor and ground cable harvest (Megahan, 1988). Road construction and use during timber harvest activities is probably the single greatest contributor to surface erosion in the eastern US (Patric, 1976), the southern US (Vowell, 1985), and in the western US (Megahan, 1988), where it also leads to accelerated mass flow (Grigal, 2000).

\section{Effects of Forest Harvesting on Soil Physical and Hydraulic Properties}

Methods for harvesting forests may cause significant impacts to soils. The soil is highly sensitive to ground harvesting techniques. Soil compaction affects soil density and porosity as well as soil water retention and hydraulic conductivity (Mudgal et al., 2010). Jansson and Johansson (1998) found that the depth to which soil physical parameters were influenced by traffic was about the same for tracked and wheeled vehicles. Their finding 
is in agreement with their hypothesis that the mass of the machine rather than the type of ground contact determines the depth to which soil physical parameters are altered. Additionally, there is a strong relationship between the degree of compaction and the physical properties of the soil. Compaction effects have been found to be strongly dependent on soil texture and soil water regime (Gomez et al., 2002).

Higher water content reduces soil strength which allows the soil to be more compacted with a similar load (Gomez et al., 2002). Sands are usually more resistive to soil compaction while silt loam materials are more sensitive to increased loads (Powers et al., 2005). These results indicate that forest harvest management will be more detrimental to soils at higher water content.

Bulk Density and Soil Strength Findings on several North American Long-Term Soil Productivity (LTSP) installations indicated that soil compaction was short-lived and did not impact tree growth after 5 to 10 years (Eaton et al., 2005; Sanchez et al., 2006; Powers et al., 2005). However, soil texture and pre-harvest bulk densities had a large effect on productivity results and density recovery rates. As compared to coarse-textured soils, finetextured soils often have lower initial bulk density levels, but the largest increase after a logging treatment, with a majority of compaction occurring after a single equipment pass (Williamson and Neilsen, 2000; Page-Dumroese et al., 2006). Sites with initially high bulk density values, probably due to old abandoned fields after decades of agriculture, could not be compacted much further. Clayey and loamy soils exhibited the greatest timber growth reductions following compaction treatments versus sandy soils where productivity was actually enhanced following compaction (Powers et al., 2005). It is believed that 
compaction increased soil moisture availability in these course-textured soils (Gomez et al., 2002).

In a study on the effects of different levels of soil compaction in North Carolina, three levels of compaction were applied to harvested loblolly pine (Pinus taeda L.) plots. The compaction treatments were no compaction $\left(\mathrm{C}_{0}\right)$, moderate compaction $\left(\mathrm{C}_{1}\right)$, and severe compaction $\left(\mathrm{C}_{2}\right)$ with bulk density values of $1.33,1.46$, and $1.45 \mathrm{Mg} \mathrm{m}^{-3}$, respectively. In this study, the researchers found that increasing levels of soil compaction resulted in a trend towards decreasing mean stand volumes (Sanchez et al., 2006). Their observation was consistent with research indicating that compaction reduces root growth and ultimately stand productivity (Morris and Miller, 1994; Fleming et al., 1998; Williamson and Neilsen, 2000). Siegel-Issem et al. (2005) used a seven by seven factorial greenhouse experiment to assess root growth as a function of bulk density and volumetric water content. The experiment demonstrated, in general, trees grown on soils with lower densities have better ability to grow well across a broader range of soil moisture conditions. Effects on soil properties following treatment also change with depth; Blanco-Canqui et al. (2004) found that bulk density increased from 1.47 to $1.52 \mathrm{Mg} \mathrm{m}^{-3}$ and organic matter decreased from 15.5 to $14.0 \mathrm{~g} \mathrm{~kg}^{-1}$ with depth $(\mathrm{P}<0.01)$. For claypan soils with argillic horizons, the magnitude of desiccation cracking and water depletion, which directly influence bulk density, are affected by soil texture and mineralogy (Baer and Anderson, 1997); with water depletion and desiccation cracking, bulk density increases.

Before the North American LTSP study, most field research of compaction of forest soils had been generally retrospective, and centered on growth comparisons between trees on log landings and skid trails, and on less-disturbed land nearby (Powers et al. 1990). A 
study by Hatchell et al. (1970) showed that naturally regenerated pine seedlings in compacted skid trails were less than half as tall as those away from skid trails in the Lower Coastal Plain of South Carolina and Virginia. In Washington, Froehlich et al. (1986) reported that volumes of 9 to 18 -year-old ponderosa pine growing in compacted skid trails 23 years after yarding activities averaged about 20 percent less than for those in less-dense soils nearby. Additionally, a study in California by Helms et al. (1986) reported that 16year-old pine growing in skid trails and log landings where bulk densities averaged $1.19 \mathrm{~g}$ $\mathrm{cm}^{-3}$ were 13 percent shorter and had 22 percent less volume (Helms and Hipkin, 1986) than adjacent trees growing in soil densities averaging $0.83 \mathrm{~g} \mathrm{~cm}^{-3}$. Overall yield was reduced by 10 percent (Helms and Hipkin, 1986).

A comparison of tracked versus wheeled machines by Jansson and Johansson (1998) found that both machines increased bulk density to a depth of 40-50 cm compared with the control treatment. Cullen et al. (1991) reported no increase in bulk density below $30 \mathrm{~cm}$ in soils trafficked by rubber-tired skidders or crawler tractors while Jakobsen and Greacen (1985) found that the change in soil physical properties reached at least $70 \mathrm{~cm}(26$ ton harvesting unit). In a study involving winter and summer trafficked sites, Block et al. (2002) found that bulk density increased significantly at 10- and 20-cm soil depths for both winter and two of the three summer harvested sites. Soil bulk density and mechanical resistance were increased from forest grazing which reduced soil porosity and water infiltration (Krzic et al., 2006).

The environment under which soils have formed plays a major role in determining the bulk density of the undisturbed soil. Compaction has been shown to be strongly related to the original bulk density, forest type, and soil parent material (Williamson and Neilsen, 
2000). In a study by Tiarks and Haywood (1996), tree heights were shortest on disked plots probably due to higher soil strength which limited root growth.

Soil Water Retention For a given region, soil type, and tree species, forest productivity is a function of volumetric water content as it varies with climate across the growing season (Siegel-Issem et al., 2005). In Missouri, it has been determined that soil water content is much greater in no-till versus tilled treatments for the upper soil depths at soil water pressures less than $-20 \mathrm{kPa}$; the van Genuchten relationship was used to fit these water retention curves. For the deeper depths (30 to $40 \mathrm{~cm}$ ), water content was higher in a tilled soil than in the no-tilled soil for all pressures; however, this was likely attributed to the claypan being at a shallower depth for the tilled site because erosion has occurred to a greater extent with continuous cultivation (Mudgal et al., 2010).

None of the sites in the North American Long-Term Soil Productivity Study had an appreciable component of shrink-swell clays (Page-Dumroese et al., 2006). In a study investigating changes in soil hydraulic properties in a regenerating rain forest, Deuchars et al. (1999) found that infiltration rate increased with increasing forest age and the water release characteristic reverted gradually from one with greater water retention at all matric potentials in the pasture plot towards that found in the primary forest.

Wide-tired skidders operating on poorly structured medium-textured boreal forest soils did not significantly affect the shape of water retention curve and pore size distributions when the soils were drier than field capacity. At greater soil water contents, the effects were limited to the air-filled pores, which suggests that damage to soil structure is lessened and integrity of the aggregates is maintained despite the compaction (Startsev 
and McNabb, 2001). A comparison of a range of equipment masses during harvest activities by Vossbrink and Horn (2004) determined that the mass of the different vehicle types was not the only reason for the increase in soil stresses and precompression stresses. Even the lighter mass equipment was able to cause high stresses, thus a complete picture of the harvesting procedure requires the inclusion of the load, soil strength, water content and hydraulic properties, and furthermore this assessment must also consider the land relief.

Saturated Hydraulic Conductivity Soil hydraulic properties are dynamic and are affected by many factors. These factors include soil structure (Fuentes et al., 2004), biological plants and organisms that grow and decay (Beven and Germann, 1982; Meek et al., 1992), shrink-swell cracks in clay soils (Baer and Anderson, 1997), and agricultural activities such as tillage and traffic compaction (Udawatta et al., 2008; Fuentes et al., 2004). In a study determining saturated hydraulic conductivity $\left(\mathrm{K}_{\mathrm{Sat}}\right)$ in a tilled versus native undisturbed field, Mudgal et al. (2010) determined that $\mathrm{K}_{\text {Sat }}$ was almost 57 times higher at the undisturbed site $\left(316 \mathrm{~mm} \mathrm{~h}^{-1}\right)$ than at the tilled site $\left(5.55 \mathrm{~mm} \mathrm{~h}^{-1}\right)$. This difference was likely caused by the differences in porosity and bulk density. Variations in soil hydraulic properties could be explained by the differences in land cover and management (compaction, tillage) but also by the loss of topsoil and the thinning of the layer above the claypan (Mudgal et al., 2010).

Williamson and Neilsen (2000) found that $\mathrm{K}_{\text {Sat }}$ showed a pattern of reduction with increasing compaction but there was no overall relationship with bulk density. In a study by Reynolds and Zebchuk (1996), results suggest that the magnitude, range, and pattern of 
variability of $\mathrm{K}_{\mathrm{fs}}$ (field saturated hydraulic conductivity) measurements were controlled primarily by the well-developed and stable soil structure at the field site, rather than by texture, organic $\mathrm{C}$, or surface topography. On most soils following harvest activities, the greatest reduction in hydraulic conductivity occurs in the 0 - to $10-\mathrm{cm}$ soil layer. Greater damage to wet soils is associated with deformation and displacement, rather than with in situ compaction. Soils with higher moisture content visually deteriorate following fewer machine passes (Froelich, 1972; Murphy, 1982) (Williamson and Neilsen, 2000). In one study, researchers found that field effective hydraulic conductivity, $\mathrm{K}$, values of the top 90 $\mathrm{cm}$ of the profile for mature plantation forest were 60 to $95 \mathrm{~m} /$ day, which were 20 to 30 times the values given in the soil survey for the Deloss series. Harvest activities did not appear to affect those $\mathrm{K}$ values, but site preparation for regeneration, including bedding, reduced the $\mathrm{K}$ to values typically assumed for the Deloss series, $3.6 \mathrm{~m} / \mathrm{d}$ for the top $45 \mathrm{~cm}$ and $1.6 \mathrm{~m} / \mathrm{d}$ for deeper layers (Skaggs et al., 2006).

Infiltration Casermeiro et al. (2003) showed that plant cover was the main factor reducing surface runoff and movement of sediments. In another study, Trojan and Linden (1998) found that residues on the surface significantly increased steady infiltration rates and the time required to reach steady-state values. Kumar et al. (2012) demonstrated that agroforestry buffer areas have higher infiltration rates which imply lower runoff compared to pasture areas. The fraction of precipitation available for stream flow, increased rates of snowmelt, and modified runoff pathways to the stream channel are increased with forest harvesting (Moore and Wondzell, 2005). 
Pore Size Distribution Where soil compaction occurs, total porosity decreases and soil strength and volumetric water content increase, resulting in increased water runoff and soil erosion, less rooting volume, and poor aeration (Greacen and Sands, 1980; Elliot et al., 1998; Williamson and Neilsen, 2000; Powers et al., 1990). In an extensive literature review, Sanchez et al. (2006) found that soil porosity was one of two site properties most likely to impact long-term productivity. Mudgal et al. (2010) found that conservation practices causing compaction to the soil resulted in a significant decrease in the occurrence of coarse and fine mesopores in the upper $30 \mathrm{~cm}$ soil depth. Brais (2001) found stem volume to increase in coarse textured soils and linked this increase to harvest traffic compaction causing a more favorable pore-size distribution, which improved the balance between aeration porosity and available water holding capacity. Page-Dumroese et al. (2006) found that change in pore-size distributions on two of the LTSP study sites may indicate that while bulk density has decreased five years after compaction activities, macroporosity may not have recovered. Additionally, Page-Dumroese et al. (2006) concluded that loss of macropores on fine-textured soil may prove to be more deleterious to plant growth than a percent change in bulk density. An experiment by Seigel-Issem et al. (2005) showed that compaction increased bulk density for four soils representing contrasting forest soils and resulted in a reduction in total porosity in all four soils.

Powers et al. (1990) believed that root growth decreases with decreasing root water potential and/or increasing soil strength, and plant stress increases as soil macroporosity decreases to a critical minimum. The conclusion was made that growth decline is likely after substantive compaction, and that it is related to loss in total soil porosity (Powers et al., 1990). Sands et al. (1979) hypothesized that compaction-caused reductions in total 
porosity may result in little change in moisture retention, and therefore plant growth proceeds relatively unaffected until root growth is inhibited; however, Gomez et al. (2002) found that changes in pore-size distribution are highly dependent on soil texture and soil water regime, and did not preclude the use of soil porosity as a monitoring tool for managers. Further, the concept of non-limiting water range (NLWR) combines the effects of several soil properties and describes the range in which water availability is non-limiting to plants. This concept states that as porosity decreases, the NLWR becomes narrower, with mechanical resistance becoming limiting at the dry end and poor aeration becoming limiting at the wet end (Letey, 1985). Seigel-Issem et al. (2005) found a decrease in root length density in three of four soils for trees grown outside this optimal range following compaction.

Macropores affect infiltration of water and solutes in soil (Trojan and Linden, 1998). Messing et al. (1997) found that dry bulk densities were generally smaller and the macroporosities larger under tree crops compared with ley/cereal crops. Saturated hydraulic conductivities also tended to be larger under the tree crops. Slopes of the linear regression lines between saturated hydraulic conductivity and each of the parameters, dry bulk density, porosity and macroporosity were steeper in the soil under agricultural crops than under tree crops. Observed differences in physical properties were considered to be an effect of land use, which had brought about changes in aggregate stability, pore size distribution, and pore continuity (Messing et al., 1997).

During the LTSP study, Powers et al. (2005) observed that soil bulk density was increased by compaction treatments, but increases were greater for soils of low to moderate initial densities and soils with initial bulk densities greater than $1.4 \mathrm{Mg} \mathrm{m}^{-3}$ showed little 
increase. Diminished increase can be attributed to finer pore sizes at higher bulk densities and the difficulty of compressing water-filled soil pores. Density recovery was also found to be very slow (Powers et al., 2005). The researchers found that growth tended to be reduced by compaction treatments on the clayey soils and increased on the sandy soils. These effects were attributed to losses of aeration porosity on clays and improvements in available water holding capacity on sands (Powers et al., 2005). Kim et al. (2010) found that differences between uniformly compacted and non-compacted plots for macropore parameters were most pronounced in the upper $10 \mathrm{~cm}$ and that differences between treatments were not significant below $20 \mathrm{~cm}$.

Management for Improving Harvested Areas A need exists for optimization of harvest management; demand for non-timber forest products and services such as water supply and quality, biodiversity and habitat, recreation opportunities, carbon sequestration, and biomass for energy and transportation fuels will continue to increase on all forest lands. This added demand for energy biomass and carbon sequestration create conflicting objectives (Burger, 2009). Several techniques exist to improve harvested areas. Recontouring techniques on forest roads can result in lower bulk densities, less surface runoff and sediment production, and greater seedling growth than both traditional and subsoiling road retirement methods, however, the cost of recontouring is greater than subsoiling or traditional retirement. Preliminary analysis indicates that subsoiling may represent the most economically viable retirement method (Kolka and Smidt, 2004). Additionally, compaction of some coarse-textured soils can actually improve moisture relations for tree growth while loamy soils are more susceptible to compaction; clayey soils 
are more susceptible to rutting and churning (Miller et al., 2004). Additionally, many best management practices can be applied during harvest activities such as use of predesignated routes which will be compacted during harvesting to minimize the extent of the affected areas and avoidance of forest roads when they are wet, soft, and easily damaged (Enyart, 2009). 


\section{REFERENCES}

Baer, J.U., and S.H. Anderson. 1997. Landscape effects on desiccation cracking in an Aqualf. Soil Science Society America Journal 61:1497-1502.

Beven, K., and P. Germann. 1982. Macropores and water flow in soils. Water Resource Research 18:1311-1325.

Blanco-Canqui, H., Gantzer, C. J., Anderson, S. H., \& Alberts, E. E. (2004). DIVISION S-6-SOIL \& WATER MANAGEMENT \& CONSERVATION Tillage and Crop Influences on Physical Properties for an Epiaqualf. Soil Sci. Soc. of Am. J, 68, 567576.

Block, R.K., C. J. Van Rees, and D. J. Pennock. 2002. Quantifying Harvesting Impacts using Soil Compaction and Disturbance Regimes at a Landscape Scale. Soil Sci. Soc. Am. J. 66: 1669-1676.

Brais, S. 2001. Persistence of soil compaction and effects on seedling growth in Northwestern Quebec. Soil Sci. Soc. Am. J. 65:1263-1271.

Burger, James A. "Management Effects on Growth, Production and Sustainability of Managed Forest Ecosystems: Past Trends and Future Directions." Forest Ecology and Management 258, no. 10 (October 2009): 2335-46.

doi:10.1016/j.foreco.2009.03.015

Butnor, J.R., Johnsen, K.H., Sanchez, F.G. 2006. Whole-tree and forest floor removal from a loblolly pine plantation have no effect of forest floor $\mathrm{CO}_{2}$ efflux 10 years after harvest. , Forest Ecology and Management, Volume 227, Issues 1-2, 15 May 2006, Pages 89-95 
Casermeiro, M.A., J.A. Molina, M.T. de la Cruz Caravaca, J. Hernando Costa, M.I. Hernando Massanet, and P.S. Moreno. "Influence of Scrubs on Runoff and Sediment Loss in Soils of Mediterranean Climate." CATENA 57, no. 1 (June 2003): 91-107. doi:10.1016/S0341-8162(03)00160-7.

Cullen S.J., Montagne C, Ferguson H (1991). Timber harvest trafficking and soil compaction in western Montana. Soil Sci. Soc. Am. J. 55:1416-1421.

Deuchars, S.A., Townend, J., Aitkenhead, M.J., FitzPatrick, E.A., 1999. Changes in soil structure and hydraulic properties in regenerating rain forest. Soil Use Manag. 15, $183-187$.

Dey, Daniel C., Johnson, Paul S.; Garrett, H.E. 1996. Modeling the regeneration of oak stands in the Missouri Ozark Highlands. Canadian Journal of Forest Research. 26(4): $573-583$.

Eaton, R.J., Spaine, P., Sanchez, F.G. 2005. Harvest Intensity and Competition Control Impacts on Loblolly Pine Fusiform Rust Incidence. In: Proceedings of the $13^{\text {th }}$ Biennial Southern Silvicultural Research Conference. 2005 Feb. 28-Mar. 4; Memphis, TN.: U.S. Department of Agriculture, Forest Service Southern Research Station. 61-64.

Elliot, W.J., Page-Dumroese, D.S., and Robichaud, P.R. 1998. The effect of forest management on erosion and soil productivity. In Soil Quality and Erosion. Edited by R. Lal. St. Lucie Press, Boca Raton, Fla. pp. 195-209.

Enyart, Doug. Missouri Woody Biomass Harvesting: Best Management Practices Manual. Missouri Department of Conservation, 2009. 
Fleming, R., Foster, N., Jeglum, J., Hazlett, P., 1998. Soil compaction and sustainable productivity on coarse-textured jack pine sites. In: Lowe, A.T., Smith, C.T. (composers), Developing Systems for Integrating Bioenergy into Environmentally Sustainable Forestry. Proceedings of the International Energy Agency Bioenergy Agreement Task, vol. 18, Nokia, Finland, pp. 72-81.

Froehlich, H. A., 1972. Soil compaction: implication for young growth management. In: Managing Young Forests in the Douglas Fir Region, Volume 4, School of Forestry, Oregon State University.

Froehlich, H.A., 1977. The physical effects of timber harvesting on forest soils. In: Proceedings of the Society of American Foresters National Convention, pp. 229 \pm 237 .

Froehlich, H.A., Miles, D.W.R., and Robbins, R.W. 1986. Growth of young Pinus ponderosa and Pinus contorta on compacted soils in central Washington. Forest Ecol. Manage. 15: 285-294.

Fuentes, J.P., M. Flury, and D.F. Bezdicek. 2004. Hydraulic properties in a silt loam soil under natural prairie, conventional till, and no-till. Soil Science Society America Journal 68:1679-1688.

Gomez, A., Powers, R. F., Singer, M. J., \& Horwath, W. R. (2002). Soil compaction effects on growth of young ponderosa pine following litter removal in California's Sierra Nevada. Soil Science Society of America Journal, 66(4), 1334-1343. Retrieved from http://search.proquest.com/docview/216054497?accountid=14576

Greacen, E.L., and Sands, R. 1980. Compaction of forest soils. A review. Aust. J. Soil Res. 18: 163-189. 
Grigal, David F. "Effects of Extensive Forest Management on Soil Productivity.” Forest Ecology and Management 138, no. 1 (2000): 167-85.

Hatchell, G.E., Ralston, C.W., and Foil, R.R. 1970. Soil disturbances in logging. J. For. 68: 772-775.

Helms, J. A. and C. Hipkin. 1986. Effects of soil compaction on tree volume in a California ponderosa pine plantation. Western J. Appl. For. 1(4): 121-124.

Helms, J. A., C. Hipkin, and E.B. Alexander. 1986. Effects of soil compaction on height growth of a California ponderosa pine plantation. Western J. Appl. For. 1(4): 104108.

Jakobsen, B.F. \& Greacen, E.L. Compaction of sandy forest soils by forwarder operations. Soil Till. Res., 5:55-70, 1985.

Jansson, K. J., and J. Johansson. "Soil Changes after Traffic with a Tracked and a Wheeled Forest Machine: a Case Study on a Silt Loam in Sweden.” Forestry 71, no. 1 (1998): 57-66.

Johnson, Paul S. 1979. Shoot elongation of black oak and white oak sprouts. Canadian Journal of Forest Research. 9(4): 489-494.

Kim, HyeMin, S.H. Anderson, P.P. Motavalli, and C.J. Gantzer. "Compaction Effects on Soil Macropore Geometry and Related Parameters for an Arable Field." Geoderma 160, no. 2 (December 2010): 244-51. doi:10.1016/j.geoderma.2010.09.030.

Kiran, G. Sandhya, and M. Kaur. "Economic Valuation of Forest Soils." Current Science (00113891) 100, no. 3 (2011). http://search.ebscohost.com/login.aspx?direct=true\&profile=ehost\&scope=site\&autht ype $=$ crawler $\& j n n l=00113891 \& A N=60463898 \& h=X U w 1 V Y n t 28 H W 4 p o f u G W D y A 0$ 
cR9SOYnws3qZ0mVvcORrX6Hnd6qizX3Ryn4HbhdYrEHCdr6QYHD3ixRqKkXB $8 \% 2 \mathrm{BA} \% 3 \mathrm{D} \% 3 \mathrm{D} \& \mathrm{crl}=\mathrm{c}$.

Kolka, R. K., \& Smidt, M. F. (2004). Effects of forest road amelioration techniques on soil bulk density, surface runoff, sediment transport, soil moisture and seedling growth. Forest Ecology and Management. doi:10.1016/j.foreco.2004.07.042

Krzic M., Newman R.F., Thethewey C., Bulmer C.E., Chapman B.K. 2006. Cattle grazing effects on plant species composition and soil compaction on rehabilitated forest landings in central interior British Columbia. Journal of Soil and Water Conservation 61, 137-144.

Kumar, Sandeep, Stephen H. Anderson, Ranjith P. Udawatta, and Robert L. Kallenbach. "Water Infiltration Influenced by Agroforestry and Grass Buffers for a Grazed Pasture System.” Agroforestry Systems 84, no. 3 (January 13, 2012): 325-35. doi:10.1007/s10457-011-9474-4.

Larsen, David R.; Loewenstein, Edward F.; Johnson, Paul S. 1999. Sustaining Recruitment of Oak Reproduction in Uneven-aged Stands in the Ozark Highlands. Gen. Tech. Rep. NC-203. St. Paul, MN: U.S. Department of Agriculture, North Central Research Station, 11 p.

Letey, J. 1985. Relationship between soil physical properties and crop and sweetgum seedlings. Can. J. For. Res. 17:970-975. production. Adv. Soil Sci. 1:277-294.

Meek, B.D., E.R. Rachel, L.M. Carter, W.R. DeTar, and A.L. Urie. 1992. Infiltration rate of a sandy loam soil: Effects of traffic, tillage, and plant roots. Soil Science Society America Journal 56:908-913. 
Megahan, W.F. 1980. Nonpoint source pollution from forestry activities in the western United States: results of recent research and research needs. Intermountain Forest and Range Experimental Station. USDA Forest Service, Boise Idaho. P.35-59 in Proc. Of Conference on U.S. Forestry and Water Quality: What Course in the 80's? Water Pollution Control Federation, June 19-20, 1980. Richmond, Virginia.

Megahan, W.F., 1988. Roads and forest site productivity. In: Lousier, J.D., Still, G.W. (Eds.), Degradation of Forested Land: Forest Soils at Risk. Proceedings of the 10th BC Soil Science Workshop, February 1986. Land Management Report 56. British Columbia Ministry of Forests, Victoria, BC, pp. 54-64.

Messing, I., A. Alriksson, and W. Johansson. "Soil Physical Properties of Afforested and Arable Land.” Soil Use and Management 13, no. 4 (1997): 209-17.

Miller, D., and Anderson, H. 2002. Soil compaction: concerns, claims, and evidence. In Proceedings, Small Diameter Timber: Resource Management, Manufacturing, and Markets, Spokane, Wash., 25-27 February 2002. Edited by D.M. Baumgartner, L.R. Johnson, and E.J. DePuit. Washington State University Cooperative Extension, Pullman, Wash. pp. 97-106.

Miller, J.H., and D.L. Sirois. 1986. Soil disturbance by skyline yarding vs. skidding in a loamy hill forest. Soil Science Society of America Journal 50:1579-1583.

Miller, R.E., Colbert, S.R., and Morris, L.A. 2004. Effects of heavy equipment on physical properties of soils and on long-term productivity: a review of literature and current research. NCASI Technical Bulletin 887. NCASI, Research Triangle Park, N.C. 
Miller, R.E., Stein, W.I., Heninger, W., Scott, W., Little, S., and Goheen, D. 1989.

Maintaining and improving site productivity in the Douglas-fir region. In

Proceedings: Maintaining the Long-Term Productivity of Pacific Northwest Forest

Ecosystems Corvallis, Ore., 1997. Edited by D.A. Perry, R. Meurisse, B. Thomas, R.

Miller, J. Boyle, J. Means, C.R. Perry, and R.F. Powers. Timber Press, Portland, Ore. pp. 98-136.

Moore, R.D. and Wondzell, S. M. 2005. Physical hydrology and the effects of forest harvesting in the Pacific Northwest: a review. Journal of the American Water Resources Association 41:763-784.

Morris, L.A., Miller, R.E., 1994. Evidence for long-term productivity changes as provided by field trials. In: Dyck, W.J., et al. (Eds.), Impacts of Forest Harvesting on Long-Term Site Productivity. Chapman and Hall, London.

Mudgal, A., S.H. Anderson, C. Baffaut, N.R. Kitchen, and E.J. Sadler. 2010. Effects of long-term soil and crop management on soil hydraulic properties for claypan soils. Journal Soil Water Conservation 65: 393-403.

Murphy, G., 1982. Soil damage associated with production thinning. N.Z. Jl For. Sci., 12 (2): 281-91.

Page-Dumroese, D, M Jurgensen, W Elliot, T Rice, J Nesser, T Collins, and R Meurisse. “Soil Quality Standards and Guidelines for Forest Sustainability in Northwestern North America.” Forest Ecology and Management, 2000. doi:10.1016/S03781127(00)00430-8.

Page-Dumroese, D., M. Jurgensen, A. Tiarks, F. Sanchez, R. Fleming, M. Kranabetter, R. Powers, F. Ponder, JR., D. Stone, J. Elioff, and A. Scott. 2006. Soil physical property 
changes on the North American Long-Term Soil Productivity (LTSP) study sites: 1 and 5 years after treatment. Can. J. For. Res. 36:551-564.

Patric, J.H., 1976. Soil erosion in the eastern forest. J. For. 74, 671-677.

Patric, J.H. 1980. Some environmental effects of cable logging in Appalachian forests. Gen. Tech. Rep. NE-55. Broomall, PA: U.S. Department of Agriculture, Forest Service, Northeastern Forest Experiment Station. 29 p.

Powers, R. F.; D. H. Alban; R.E. Miller; A. E. Tiarks; C. G. Wells; P. E. Avers; R. G. Cline; N. S. Loftus, Jr.; and R. O. Fitzgerald. 1990. Sustaining productivity in North American forests: problems and prospects. In Gessel, S. P.; Lacate, D. S.; Weetman, G. F.; and Powers, R. F., eds. Proceedings of the seventh North American forest soils conference; 1988 July 24-28; Vancouver, British Columbia. Vancouver, British Columbia. University of British Columbia: p 49-79.

Powers, R.F., Scott, D.A., Sanchez, F.G., Voldseth, R.A., Page-Dumroese, D., Elioff, J.D., Stone, D.M., 2005. The North American long-term soil productivity experiment: findings from the first decade of research. For. Ecol. Manage. 220, 31-50.

Reynolds, W.D. and Zebchuk, W.D. 1996, 'Hydraulic Conductivity in a Clay Soil: Two Measurement Techniques and Spatial Characterization', Soil Science Society of America Journal, vol. 60, pp. 1679-1685.

Routledge, R. D. "The Impact of Soil Degradation on the Expected Present Net Worth of Future Timber Harvests.” Forest Science 33, no. 4 (1987): 823-34.

Sanchez, F.G., Scott, F.G., Ludovici, K.H., 2006. Negligible effects of severe organic matter removal and soil compaction on loblolly pine growth over 10 years. For. Ecol. Manage., in press. 
Sands, R., Greacen, E.L., and Gerard, C.J. 1979. Compaction of sandy soils in radiata pine forests: I. A penetrometer study. Aust. J. Soil Res. 17: 101-113.

Sidle, R.C. 1980. Impacts of forest practices on surface erosion. Department of Forest Engineering, Oregon State University, Corvallis. 29 p.

Siegel-Issem, C.M.; J. A. Burger; R. F. Powers; F. Ponder; and S. C. Patterson. 2005. Seedling Root Growth as a Function of Soil Density and Water Content. Soil Science Society of America Journal. 69: 215-226.

Skaggs, R. Wayne; Amatya, Devendra M.; Chescheir, G. M.; Blanton, C. D.; Gilliam, J. W. 2006. Effect of Drainage and Management Practices on Hydrology of Pine Plantation. In: Williams, Thomas, eds. Hydrology and Management of Forested Wetlands: Proceedings of the International Conference, St. Joseph, MI: American Society of Agricultural and Biological Engineers: 3-14

Startsev, A.D., McNabb, D.H., 2001. Skidder traffic effects on water retention, pore-size distribution, and Van Genuchten parameters of boreal forest soils. Soil Sci. Soc. Am. J. 65 (1), 224-231.

Tiarks, A. E. and J.D. Haywood. 1996. Site preparation and fertilization effects on growth of slash pine for two rotations. Soil Science Society of America Journal 60:1654-1663.

Tiarks, A.E., M.A. Buford, R.F. Powers, J.F. Ragus, D.S. Page-Dumroese, F. Ponder, Jr., and D.M. Stone; 1997. North American Long-Term Soil Productivity Research Program. In: Communicating the role of silviculture in managing the national forests: Proceedings of the National Silviculture Workshop. 1997 May 19-22; Warren, PA.: 
Gen. Tech. Rep. NE-238. Radnor, PA: U.S. Department of Agriculture, Forest Service, Northeastern Forest Experiment Station. 140-147.

Trojan, M. D., and D. R. Linden. "Macroporosity and Hydraulic Properties of Earthworm-affected Soils as Influenced by Tillage and Residue Management.” Soil Science Society of America Journal 62, no. 6 (1998): 1687-92.

Udawatta, R.P., S.H. Anderson, C.J. Gantzer, and H.E. Garrett. 2008. Influence of prairie restoration on CT-measured soil pore characteristics. Journal of Environmental Quality 37(1):219-228.

Vossbrink, Joerg, and Rainer Horn. "Modern Forestry Vehicles and Their Impact on Soil Physical Properties." European Journal of Forest Research 123, no. 4 (December 30, 2004): 259-67. doi:10.1007/s10342-004-0040-8.

Vowell, J.L., 1985. Erosion rates and water quality impacts from a recently established forest road in Oklahoma's Ouachita Mountains. In: Blackmon, B.G. (Ed.), Proceedings of Forestry and Water Quality: A Mid-south Symposium. Little Rock, AR, May 8-9, 1985. Department of Forest Resources, University of Arkansas, Monticello, AR, pp. 152-163.

Westbrooks, R. 1998. Invasive plants, changing the landscape of America: Fact book, Federal Interagency Committee for the Management of Noxious and Exotic Weeds (FICMNEW), Washington, D.C. 109 pp.

Williamson, J.R., Neilsen, W.A., 2000. The influence of forest site on rate and extent of soil compaction and profile disturbance of skid trails during ground-based harvesting. Can. J. For. Res. 30, 1196-1205. 


\title{
CHAPTER 3
}

\section{SOIL HYDRAULIC PROPERTIES AFFECTED BY LOGGING ACTIVITIES IN A CENTRAL HARDWOOD FOREST}

\begin{abstract}
Former studies have shown that once compacted, forest soils often recover slowly (many decades) to pre-disturbed levels for soil properties such as bulk density or penetrometer resistance. This study was conducted to evaluate the effects of selected harvesting techniques on soil physical and hydraulic properties. The effects of logging roads, log landing areas, and logged areas on soil water retention, saturated hydraulic conductivity $\left(\mathrm{K}_{\mathrm{Sat}}\right)$, pore-size distributions, and bulk density were investigated on harvested sites within the Mark Twain National Forest in Callaway County, Missouri on a moderately well-drained Keswick soil (fine, smectitic, mesic Aquertic Chromic Hapludalfs). Soil cores $(7.6 \mathrm{~cm}$ by $7.6 \mathrm{~cm})$ were removed in four $10-\mathrm{cm}$ depth increments in June 2011. Bulk density was significantly greater $(\mathrm{P}<0.01)$ and $\mathrm{K}_{\text {Sat }}$ was significantly lower $(\mathrm{P}<0.01)$ under the logging road and log landing areas compared to the logged areas. No statistical differences in bulk density and $\mathrm{K}_{\text {Sat }}$ values occurred among treatments at the deepest sampling depth (30 to $40 \mathrm{~cm}$ ). For the 0 and $-0.4 \mathrm{kPa}$ soil water pressures, water retention was $11 \%$ greater and $7 \%$ greater for the logged areas versus logging road and log landing areas averaged across all soil depths, respectively. For the macropores (>1000 micrometer diameter) and coarse mesopores (60 to 1000 micrometer diameter) combined, values were 95\% greater for the logged areas compared to logging road and log landing areas within the 0 to $10 \mathrm{~cm}$ depth. From this study, the methods used in logged areas appear to have
\end{abstract}


caused small changes to soil physical and hydraulic properties; however, significant changes occurred with these properties for logging roads and the log landing.

\section{INTRODUCTION}

Various studies have shown that once compacted by harvest activities, forest soils often recover slowly to pre-disturbed levels of bulk density (Sands et al., 1979; Froehlich et al., 1985; Tiarks and Haywood, 1996). Recovery rates are dependent on many factors, but chief among them are number of repeated harvest cycles, soil moisture conditions during harvest, soil texture, and rock-fragment content (Miller et al., 1996; Williamson and Neilsen, 2000; Liechty et al., 2002). The extent of compaction, initial bulk density, depth

of impact, and subsequent soil recovery are all factors that determine the consequences of timber harvesting or site preparation on productivity (Page-Dumroese et al., 2006). In addition, duration and variability of compaction can be significant from site to site or at depth in the soil profile (Beckett and Webster, 1971; Blyth and MacLeod, 1978; Courtin et al., 1983). For instance, variability within soil textural groups, forest stands, or along skid trails can be as great as or greater than the variability between them (Courtin et al., 1983).

Compaction is caused by traffic when soils have insufficient strength to support the load (Siegel-Issem et al., 2005). When soils fail, which is an increase in density due to the excess load, the bulk density of the soil increases which gives the soil enough strength to support the load (Hillel, 1998). Ultimately, the degree of compaction caused by harvesting or site preparation is affected by soil properties (e.g., texture, organic matter, and water content) at the time of disturbance (Block and VanRees, 2002). Soil water content is one of the most important factors influencing the compactiblity of soils (Soane, 1990). Higher 
soil water content reduces the soil strength allowing greater increases in density during wet conditions (Jansson and Johansson, 1998). Wet conditions cause the soil to exhibit less strength.

Soil hydraulic properties are very sensitive to compaction (Blanco-Canqui, 2004). Jannson and Johansson (1998) found that saturated hydraulic conductivity decreased at the $10 \mathrm{~cm}$ depth by two orders of magnitude due to wheel traffic. In forested settings, compaction not only decreases production but increases runoff and erosion and negatively affects water quality (Powers et al., 1990). Thus, management is critical to maintain good hydraulic properties to minimize runoff, erosion, and water quality.

The mass of the equipment used during harvest activities plays a significant role in determining the depth to which soil physical parameters are altered. The depth to which compaction occurs is also dependent upon the soil water content (Braunack and Williams, 1993)(Jansson and Johansson, 1998). A practical recommendation is to minimize traffic in order to affect the soil as little as possible (Jansson and Johansson, 1998).

Maintaining optimal soil hydraulic properties in forest managed sites is critical for environmental conservation. Although the effects of timber harvest on bulk density have been studied considerably, not many studies have been conducted on harvest activity effects on hydraulic properties on soils. The purpose of this study was to assess the effects of different levels of timber harvesting traffic on soil bulk density, saturated hydraulic conductivity, soil water retention, and pore size distributions. 


\section{MATERIALS AND METHODS}

\section{Experimental Site History}

The area selected for this study was located on the Cedar Creek unit of the Mark Twain National Forest near Fulton, Missouri. This site was historically settled by Europeans approximately 200 years before present. The site was initially managed under private ownership until the 1940s. Most European settlers in the 1800s through the early 1900s used the land for timber harvesting. After clearing, these lands were subsequently used as grazing land for cattle and other livestock. Some small areas were probably managed for hay as well as corn (Zea maze) and wheat grain (Triticum aestivum) crops. Some vegetable production occurred near homesteads (US Forest Service, 2004).

The forests originally consisted of an oak-hickory mix including some other less dominant species. Recent surveys indicate the land contains about $45 \%$ oak-hickory, $12 \%$ cedar and other hardwoods, about $6 \%$ bottomland hardwoods, and $1 \%$ locusts (Kingsley and Law, 1991). The oaks include white (Quercus alba), red oak group (pin oak (Q. palustris), northern red oak (Q. rubra), and black oak ( $Q$. velutina)). The other $38 \%$ of the land is open (usually pasture with fescue and some warm season grasses) and brush.

Most of the land of the Cedar Creek unit was acquired by the U.S. federal government during the 1940's under Title II of the Bankhead Jones Act of 1937 (US Forest Service, 2004). Under the Act, the USDA-Soil Conservation Service, now the Natural Resource Conservation Service (NRCS), undertook a restoration program to improve the land. Most of the land was degraded due to overgrazing, cropping on unsuitable soils, and clearing of timber (US Forest Service, 2004). Conservation 
management included fencing of water resources and pastures to control grazing.

Pastures were also managed with rotational grazing (US Forest Service, 2004).

\section{Experimental Site Information}

For the experimental site, the average temperature in winter is -0.4 degrees $\mathrm{C}$ and the average daily minimum temperature is -5.5 degrees $C$ ( 30 year average). In summer, the average temperature is 23.7 degrees $\mathrm{C}$ and the average daily maximum temperature is 29.6 degrees. The total annual precipitation is $114.4 \mathrm{~cm}$. The average seasonal snowfall is about $49.8 \mathrm{~cm}$ (USDA, 1992; Guinan, 2013). The soils in the harvested areas were mapped as Keswick loam (Fine, smectitic, mesic Aquertic Chromic Hapludalfs). These soils are formed in a thin layer of pedisediments with an underlying weathered glacial till.

Soil profiles were studied from samples taken from a representative location within one of the Logged Area-recent treatments in May of 2013. Analyses were conducted for the soil horizons and data on soil physical and chemical properties for the site are shown in Table 3.1. Clay content, silt content, CEC, organic matter, and water $\mathrm{pH}$ $\left(\mathrm{pH}_{\mathrm{w}}\right)$ are shown for the upper soil horizons in the table. In this study area, the claypan occurred at about the $18 \mathrm{~cm}$ depth on the average.

The study was conducted in portions of four harvested areas that are delineated by vegetative type into timber stands within the Cedar Creek unit. The treatments for this experimental study were defined as follows: historical logged area (Logged Area-H), recent logged area (Logged Area-R), logging road (Logging Road), and log landing area (Log Landing). Oak and hickory were the dominant species in these stands. The oak and hickory was harvested in October and November of 2007. For wildlife enhancement 
purposes, the Forest Service determined a need to provide $40-50$ percent of the sawtimber component of woodland habitat exhibiting a condition of 20-30 percent forbs, grass, and shrub ground cover (US Forest Service, 2004). Size of trees selected for harvest were 30 cm DBH or larger.

Table 3.1. Soil physical and chemical properties for the study location (Keswick silt loam) (5 to $9 \%$ slope) presented by profile horizon with standard deviations indicated in parentheses.

\begin{tabular}{ccccccc}
\hline $\begin{array}{c}\text { Soil } \\
\text { Horizon }\end{array}$ & $\begin{array}{c}\text { Soil } \\
\text { Depth }\end{array}$ & Sand & Silt & Clay & $\begin{array}{c}\text { Organic } \\
\text { Matter }\end{array}$ & $\mathrm{pH}_{\mathrm{w}}$ \\
\hline & $\mathrm{cm}$ & $\mathrm{g} \mathrm{kg}^{-1}$ & $\mathrm{~g} \mathrm{~kg}^{-1}$ & $\mathrm{~g} \mathrm{~kg}^{-1}$ & $\mathrm{~g} \mathrm{~kg}^{-1}$ & \\
$\mathrm{~A}$ & $0-10$ & $19.6(3.32)^{\mathrm{t}}$ & $808.7(2.9)$ & $171.8(0.5)$ & $28.8(5.0)$ & $5.21(0.26)$ \\
$\mathrm{AE}$ & $10-18$ & $18.1(0.67)$ & $833.2(27.0)$ & $148.6(26.4)$ & $9.55(0.42)$ & $4.83(0.10)$ \\
$\mathrm{BE}_{1}$ & $18-28$ & $15.4(0.72)$ & $760.4(28.0)$ & $224.1(27.3)$ & $12.83(3.99)$ & $4.71(0.05)$ \\
$\mathrm{BE}_{2}$ & $28-40$ & $13.0(0.01)$ & $708.3(0.19)$ & $278.7(0.18)$ & $3.08(4.33)$ & $4.58(0.04)$ \\
$2 \mathrm{Bt}$ & $40-60$ & $14.2(1.70)$ & $542.8(28.0)$ & $443.0(26.4)$ & $2.90(2.50)$ & $4.60(0.05)$
\end{tabular}

${ }^{t}$ Number in parenthesis is the standard deviation of the mean of 2 observations.

Four replicate harvested areas were selected and used to investigate the effects of logging management on soil physical properties. The Logged Area-R treatment was harvested in October and November 2007 using uneven-aged harvest methods. The historically logged area was harvested 70 years before present with clear cutting. There were four treatments with four replicates of each treatment. Within the Logged Area- $R$ treatment, the harvesting equipment used to retrieve the logs from the logged area through the logging road to the log landing was a rubber-tired skidder. Axel loads of the 
skidder were 6.8 metric tons with $71 \mathrm{~cm}$ wide tires. Soil water content conditions were relatively moist (slightly below field capacity) during harvest activities. The logs at the landing were stacked approximately $2.0 \mathrm{~m}$ high about six logs deep.

\section{$\underline{\text { Sampling Procedures }}$}

Undisturbed soil cores, $7.6 \mathrm{~cm}$ in diameter and $7.6 \mathrm{~cm}$ in length, were taken to determine soil water retention, porosity, saturated conductivity ( $\mathrm{K}_{\text {Sat }}$ ), and bulk density. The cores were taken from the areas June 9-14, 2011. Samples were taken from each treatment of each replication. Sample cores were taken in the center areas of the Log Landing and Logging Road treatments. Cores were taken in proximity of a harvested tree in the Logged Area- $\mathrm{R}$ treatment and in selected random locations in the Logged Area-H treatment. Samples were taken from four depths: 0 to $10 \mathrm{~cm}, 10$ to $20 \mathrm{~cm}, 20$ to $30 \mathrm{~cm}$, and 30 to $40 \mathrm{~cm}$. These depths corresponded in part to soil horizons: the first two depths were in the $\mathrm{A}$ or $\mathrm{AE}$ horizon and the third and fourth depths were in the $2 \mathrm{Bt}$ horizon. The samples were then secured in plastic bags, transported to the University of Missouri Anheuser-Busch Natural Resources Building, and stored in cold rooms at $4.0^{\circ} \mathrm{C}$ until laboratory measurements were conducted.

\section{Laboratory Analysis}

For the saturated hydraulic conductivity measurement, the samples were removed from the cold room and the plastic bags were removed from each of the samples. A disc was used to cover the top of the sample and flip it over without losing the core's contents. The disc which was taped on the base of the core was then removed and cheese cloth was 
attached to the base of the sample with a rubber band. The sample was then flipped back over, an additional sample core ring of the same dimensions was connected to the top of the sample with a bicycle inner tube, and the sample was placed in a tub. Water was then incrementally added to the tub over the course of 72 hours to allow the samples to saturate. Bentonite slurry was applied around the edge of the surface of the soil sample to fill any openings along the core walls. Once fully-saturated, a constant head permeameter unit was used to maintain a constant hydraulichead on the samples and saturated hydraulic conductivity measurements were taken using the constant head method. The falling head method was used for samples with constant head measurements that yielded less than $5.0 \mathrm{~mL}$ after 30 minutes.

For the water retention measurements the samples were re-saturated and transferred to a water retention unit with ceramic plates attached to a pressure regulator. Soil cores were exposed to selected pressures set at designated levels and water retention measurements were recorded for the $-0.4,-1.0,-2.5,-5.0,-10.0$ and $-20.0 \mathrm{kPa}$ readings. Following the lower pressure measurements, the samples were removed from the apparatus and air dried in an oven at $35^{\circ} \mathrm{C}$ until a constant weight was reached. Additionally, a sub-sample from each core was taken from the air-dried cores and oven dried at $105^{\circ} \mathrm{C}$ to determine oven-dry water content which was used to measure bulk density (Dane and Topp, 2002).

For the lower soil water pressures, pressure chambers connected to pressure regulators were used. Sub-samples of the air dried cores were used for measurements: aggregates were used for the -33 and $-100 \mathrm{kPa}$ water retention readings and samples passed through a $2.0 \mathrm{~mm}$ sieve was used for the $-1,500 \mathrm{kPa}$ water retention reading. 
Pore size distributions were calculated using water retention data. Four classes of pore sizes were determined: macropores (>1,000 micrometers), coarse mesopores $(60-1,000$ micrometers), fine mesopores (10-60 micrometers), and micropores ( $<10$ micrometers).

\section{Statistical Analysis}

A randomized complete block design was selected for the study site. Analysis of variance was conducted with SAS Version 9.3 using the GLM procedure (SAS Institute, 1989). Contrasts between treatments were also determined when ANOVA was run. Contrasts included 'Compacted vs. Non-Compacted' (Log Landing and Logging Road vs. Logged Area-R and Logged Area-H), 'Logged Area-R vs. Logged Area-H', and 'Logging Road vs. Log Landing'. Least significant differences between treatments were estimated at the $\mathrm{P}<0.05$ level from SAS using the appropriate error term

\section{RESULTS AND DISCUSSION}

\section{$\underline{\text { Soil Water Retention }}$}

Analysis of variance results for soil water retention as a function of soil water pressure reveal that there were no significant differences $(\mathrm{P}>0.05)$ among treatment means for any of the soil water pressures (Table 3.2). The 'compacted vs. non-compacted' contrast was significant $(\mathrm{P}<0.05)$ at 0.0 and $-0.4 \mathrm{kPa}$. The 'logging road vs. log landing' contrast was not significant for any pressure. The water contents at 0.0 and $-0.4 \mathrm{kPa}$ were significantly greater for the logged area treatments compared to the logging road and log landing treatments. The greater values for the logged area treatments were probably due 
to more compaction in the logging road and log landing treatments. Larger pores are influenced by compaction; thus more larger pores were present in less compacted treatments.

There were significant differences $(\mathrm{P}<0.01)$ due to soil depth at all soil water pressures (Table 3.2). Generally, there were greater water contents in the surface $10 \mathrm{~cm}$ compared to the second $10 \mathrm{~cm}$ depth for soil water pressures $>-20 \mathrm{kPa}$. There was an increase in water content from the second to the fourth soil depths. This was due to the higher clay content of subsoil horizons (Table 3.1). There were significant interactions $(\mathrm{P}<0.05)$ between treatment and soil depth at all of the soil water pressures $(0.0$ to -1500.0 $\mathrm{kPa}$ ). These results were probably due to more rutting and erosion in the logging road and log landing treatments and subsequently shallower depth to clay horizon, resulting in greater soil water contents as compared to the historic and recent logged area treatments.

Significant differences among treatments for specific soil depths are shown in Fig. 3.1. For the first soil depth, significantly higher $(\mathrm{P}<0.01)$ soil water content was present for the two logged area treatments compared to the logging road and log landing treatments for the 0.0 and $-0.4 \mathrm{kPa}$ pressures (Fig. 3.1A). These results were probably due to vegetation regrowth in the logged areas and less initial compaction with subsequent higher porosity compared to the logging road and log landing treatments and are similar to findings by Deuchars et al. (2011). Water content was greater for the logged area-recent treatment compared to the logging road and log landing treatments for the surface two depths at the 0.0 and $-0.4 \mathrm{kPa}$ pressures (Fig. 3.1A-B); however, there were no significant differences between treatments for the third depth for these pressures (Fig. 3.1C). The logging road treatment had greater water content than the logged area treatments for the 
fourth depth at this pressure (Fig. 3.1D). The logging road treatment had significantly greater water contents compared to the logged area treatments at all of the pressures at the fourth depth. This was probably due to more soil compaction in the logging road treatment and a subsequently faster and shallower depth to the claypan horizon, which resulted in higher soil water contents at these pressures.

In summary, there were greater soil water contents for the logged area treatments compared to the logging road and log landing treatments for the first depth at higher soil water pressures. However, there was higher water content in the logging road treatment for all of the soil water pressures for the fourth depth. Seobi et al. (2005) and Mudgal et al. (2010) found similar increases in water content at deeper depths for a claypan soil in northeast Missouri. 
Table 3.2. Water retention as a function of soil water pressure $(0.0$ to $-1500 \mathrm{kPa})$ as affected by buffer treatments and soil depth.

\begin{tabular}{|c|c|c|c|c|c|c|c|c|c|c|}
\hline & \multicolumn{10}{|c|}{ Soil water pressure $(\mathrm{kPa})$} \\
\hline & 0.0 & -0.4 & -1.0 & -2.5 & -5.0 & -10.0 & -20.0 & -33.0 & -100 & -1500 \\
\hline & \multicolumn{10}{|c|}{ 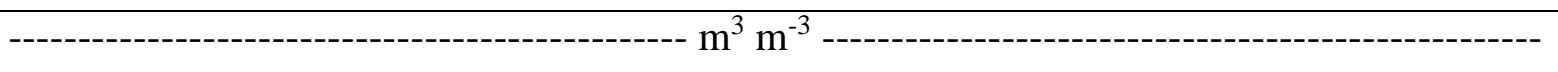 } \\
\hline \multicolumn{11}{|l|}{ Treatment mean } \\
\hline Logging Road (LR) & 0.446 & 0.451 & 0.429 & 0.405 & 0.388 & 0.373 & 0.355 & 0.275 & 0.210 & 0.141 \\
\hline Log Landing (LL) & 0.470 & 0.454 & 0.430 & 0.406 & 0.389 & 0.373 & 0.353 & 0.271 & 0.211 & 0.139 \\
\hline Logged Area-R (LAr) & 0.520 & 0.494 & 0.453 & 0.409 & 0.375 & 0.350 & 0.321 & 0.268 & 0.174 & 0.105 \\
\hline Logged Area-H (LAh) & 0.494 & 0.474 & 0.449 & 0.422 & 0.397 & 0.378 & 0.356 & 0.281 & 0.193 & 0.115 \\
\hline \multicolumn{11}{|l|}{ Depth mean } \\
\hline $0-10 \mathrm{~cm}$ & 0.530 & 0.506 & 0.465 & 0.429 & 0.396 & 0.367 & 0.339 & 0.263 & 0.185 & 0.114 \\
\hline $10-20 \mathrm{~cm}$ & 0.464 & 0.450 & 0.421 & 0.389 & 0.363 & 0.342 & 0.318 & 0.263 & 0.157 & 0.088 \\
\hline $20-30 \mathrm{~cm}$ & 0.470 & 0.451 & 0.430 & 0.402 & 0.382 & 0.368 & 0.349 & 0.297 & 0.210 & 0.135 \\
\hline $30-40 \mathrm{~cm}$ & 0.485 & 0.467 & 0.444 & 0.423 & 0.407 & 0.396 & 0.378 & 0.300 & 0.234 & 0.165 \\
\hline \multicolumn{11}{|c|}{ Analysis of variance $\mathrm{P}>\mathrm{F}$} \\
\hline Treatment & 0.073 & 0.173 & 0.443 & 0.661 & 0.508 & 0.249 & 0.108 & 0.901 & 0.274 & 0.331 \\
\hline Compacted vs. $\mathrm{NC}^{\dagger}$ & 0.020 & 0.048 & 0.123 & 0.364 & 0.818 & 0.393 & 0.161 & 0.931 & 0.089 & 0.087 \\
\hline LAr vs. LAh & 0.209 & 0.344 & 0.826 & 0.417 & 0.153 & 0.073 & 0.040 & 0.496 & 0.360 & 0.651 \\
\hline LR vs. LL & 0.846 & 0.872 & 0.950 & 0.938 & 0.926 & 0.998 & 0.912 & 0.817 & 0.962 & 0.941 \\
\hline Depth & $<0.010$ & $<0.010$ & $<0.010$ & $<0.010$ & $<0.010$ & $<0.010$ & $<0.010$ & $<0.010$ & $<0.010$ & $<0.010$ \\
\hline Treatment by Depth & $<0.010$ & $<0.010$ & $<0.010$ & $<0.010$ & $<0.010$ & $<0.010$ & 0.014 & $<0.010$ & $<0.010$ & $<0.010$ \\
\hline
\end{tabular}

${ }^{\dagger}$ Compacted included LR and LL treatments; NC referred to non-compacted which included LAr and LAh treatments. 

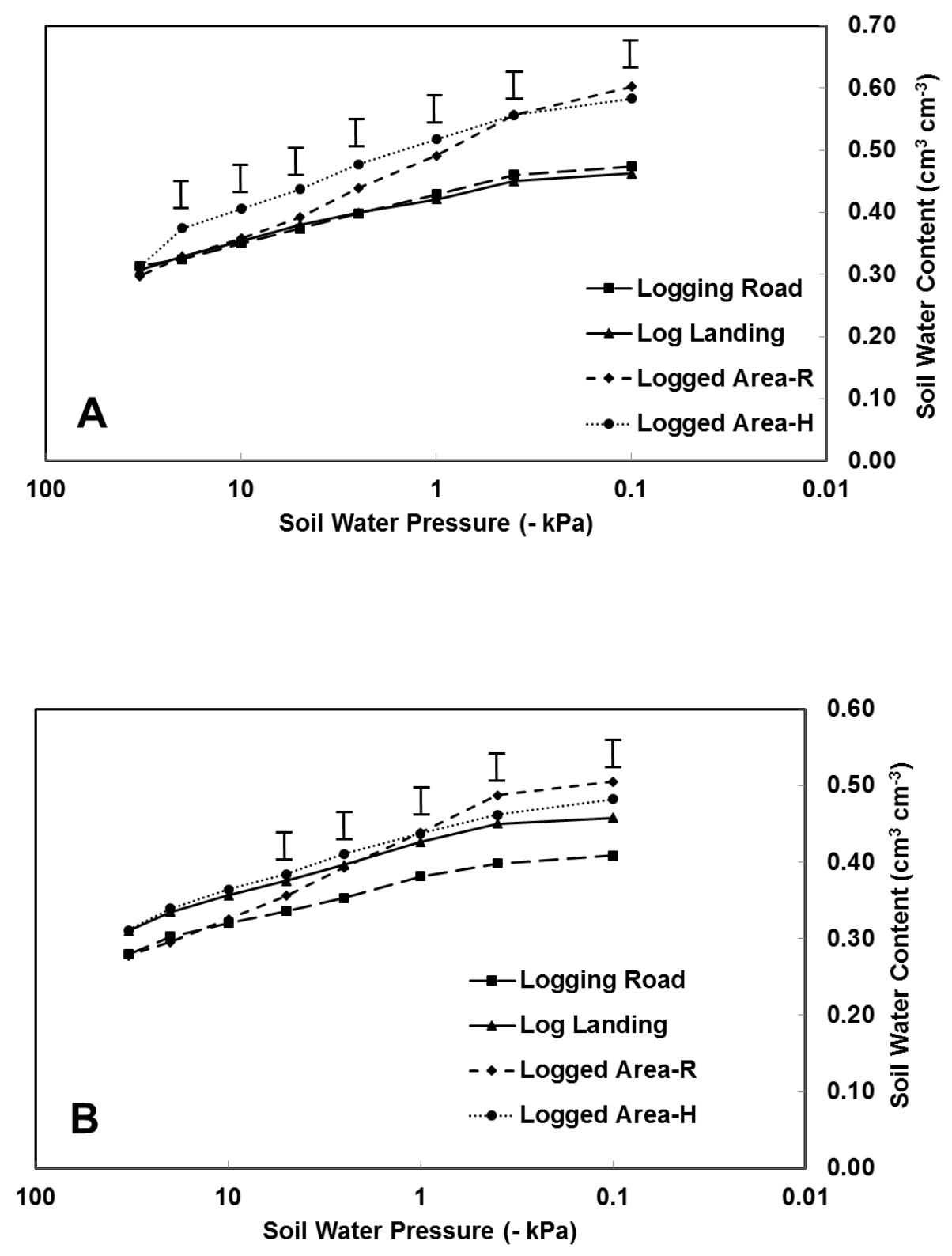

Figure 3.1. Effects of logging treatments on soil water retention at depths of A) 0 to $10 \mathrm{~cm}$, B) 10 to $20 \mathrm{~cm}$, C) 20 to $30 \mathrm{~cm}$, and D) 30 to $40 \mathrm{~cm}$. Bars indicate LSD (0.05) values and are presented at pressures when significant differences occurred among treatments. 

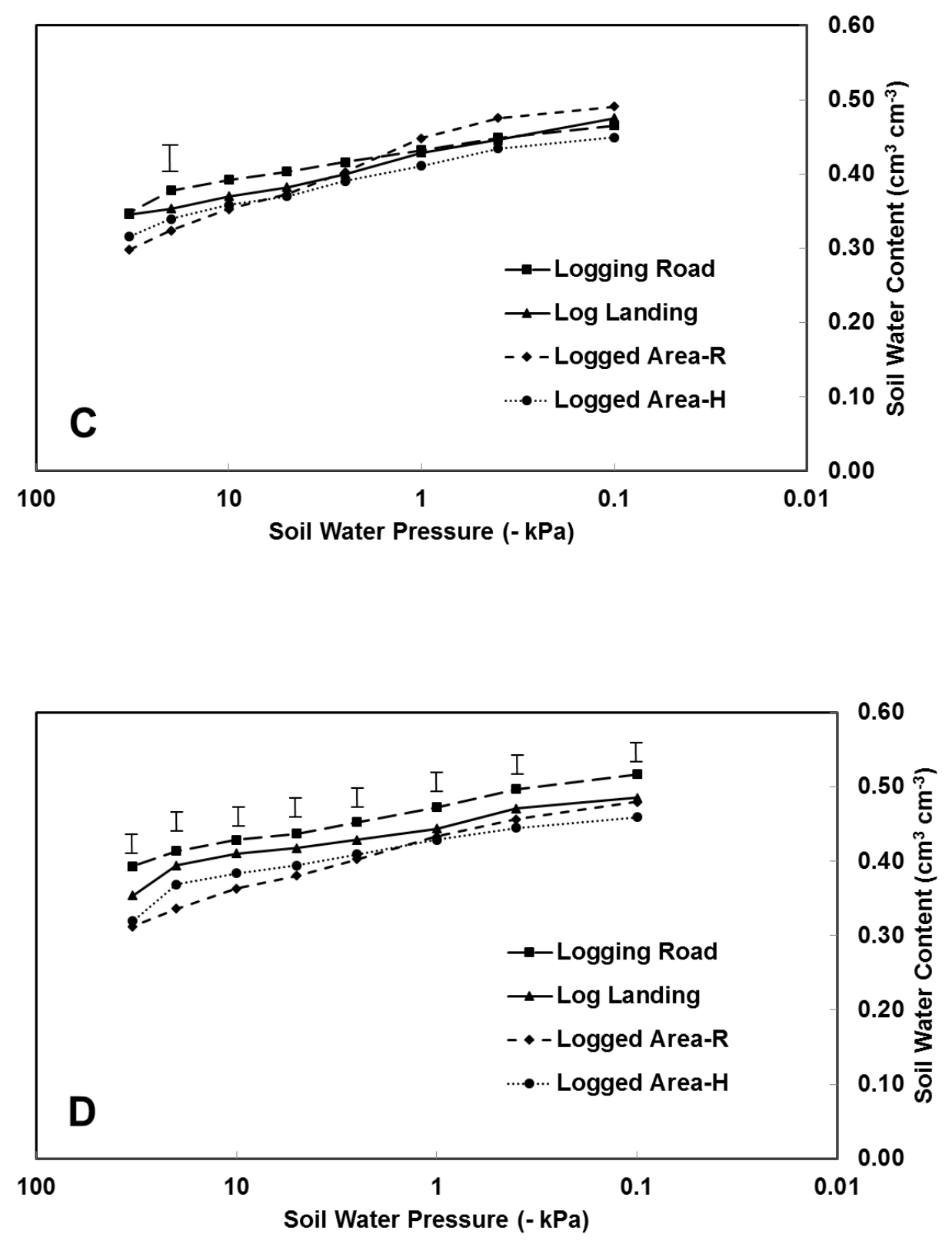

Figure 3.1 (cont.). Effects of logging treatments on soil water retention at depths of A) 0 to $10 \mathrm{~cm}, \mathrm{~B}) 10$ to $20 \mathrm{~cm}$, C) 20 to $30 \mathrm{~cm}$, and D) 30 to $40 \mathrm{~cm}$. Bars indicate LSD (0.05) values and are presented at pressures when significant differences occurred among treatments. 


\section{Pore-Size Distributions}

Logging treatments and soil depth had statistically significant $(\mathrm{P}<0.01)$ effects on coarse mesoporosity (Table 3.3). Soil depth also had a significant effect on total porosity, fine mesoporosity, and microporosity as well as coarse mesoporosity. The 'compacted vs. non-compacted' contrast indicated that the logged area treatments had more total porosity, macroporosity, and coarse mesoporosity compared to the logging road and log landing treatments. The 'logged area-recent vs. logged area-historic' contrast indicated that the logged area-recent treatment had more coarse mesopores than the logged area-historic treatment. This was probably due to the greater amount of root development from vegetative regrowth, less initial compaction, and subsequent effect on pores in the logged area treatments. There were no significant differences in macroporosity, fine mesoporosity, and microporosity among the treatments.

Soil depth had a significant effect on all pore size classes except macropores (Table 3.3). For all pore size classes, there was a decrease in porosity from the surface depth to the second depth. This was probably due to an increase in bulk density for the second depth. There was an increase in porosity with depth from the third to the fourth depths for fine mesoporosity and microporosity. Microporosity increased as a function of depth from the second to the fourth depth probably due to the increase in clay content with depth for this soil (Table 3.1). There were significant interactions between treatment and depth for all pore size classes except macroporosity (Table 3.3). 
Table 3.3. Total pores, macropores, coarse mesopores, fine mesopores, and micropores as affected by logging treatments and soil depth.

\begin{tabular}{|c|c|c|c|c|c|}
\hline Treatment & $\begin{array}{l}\text { Total } \\
\text { Pores }\end{array}$ & $\begin{array}{l}\text { Macropores } \\
(>1000 \mu \mathrm{m})\end{array}$ & $\begin{array}{c}\text { Coarse } \\
\text { Mesopores } \\
(60-1000 \mu \mathrm{m})\end{array}$ & $\begin{array}{c}\text { Fine } \\
\text { Mesopores } \\
(10-60 \mu \mathrm{m})\end{array}$ & $\begin{array}{l}\text { Micropores } \\
\quad(<10 \mu \mathrm{m})\end{array}$ \\
\hline & \multicolumn{5}{|c|}{------------------ $\mathrm{m}^{3} \mathrm{~m}^{-3}$--------------- } \\
\hline & \multicolumn{5}{|c|}{$\underline{0-10 \mathrm{~cm} \text { depth }}$} \\
\hline Logging Road (LR) & $0.474^{\mathrm{b}}$ & $0.014^{\mathrm{b}}$ & $0.086^{\mathrm{c}}$ & $0.151^{\mathrm{ab}}$ & $0.223^{\mathrm{b}}$ \\
\hline Log Landing (LL) & $0.462^{\mathrm{b}}$ & $0.012^{\mathrm{b}}$ & $0.070^{\mathrm{c}}$ & $0.162^{\mathrm{a}}$ & $0.218^{\mathrm{b}}$ \\
\hline Logged Area-R (LAr) & $0.602^{\mathrm{a}}$ & $0.045^{\mathrm{a}}$ & $0.165^{\mathrm{a}}$ & $0.095^{\mathrm{c}}$ & $0.297^{\mathrm{a}}$ \\
\hline \multirow[t]{2}{*}{ Logged Area-H (LAh) } & $0.583^{\mathrm{a}}$ & $0.026^{\mathrm{b}}$ & $0.119^{b}$ & $0.124^{\mathrm{c}}$ & $0.313^{\mathrm{a}}$ \\
\hline & \multicolumn{5}{|c|}{$10-20 \mathrm{~cm} \mathrm{depth}$} \\
\hline Logging Road (LR) & $0.409^{c}$ & $0.010^{\mathrm{a}}$ & $0.062^{\mathrm{b}}$ & $0.116^{\mathrm{a}}$ & $0.221^{\mathrm{a}}$ \\
\hline Log Landing (LL) & $0.458^{\mathrm{bc}}$ & $0.008^{\mathrm{a}}$ & $0.075^{\mathrm{b}}$ & $0.131^{\mathrm{a}}$ & $0.245^{\mathrm{a}}$ \\
\hline Logged Area-R (LAr) & $0.505^{\mathrm{a}}$ & $0.018^{\mathrm{a}}$ & $0.132^{\mathrm{a}}$ & $0.124^{\mathrm{a}}$ & $0.232^{\mathrm{a}}$ \\
\hline \multirow[t]{2}{*}{ Logged Area-H (LAh) } & $0.483^{\mathrm{ab}}$ & $0.020^{\mathrm{a}}$ & $0.078^{\mathrm{b}}$ & $0.139^{\mathrm{a}}$ & $0.246^{\mathrm{a}}$ \\
\hline & \multicolumn{5}{|c|}{$20-30 \mathrm{~cm}$ depth } \\
\hline Logging Road (LR) & $0.465^{\mathrm{a}}$ & $0.017^{\mathrm{a}}$ & $0.045^{\mathrm{b}}$ & $0.087^{\mathrm{a}}$ & $0.316^{\mathrm{a}}$ \\
\hline Log Landing (LL) & $0.475^{\mathrm{a}}$ & $0.029^{\mathrm{a}}$ & $0.064^{\mathrm{b}}$ & $0.068^{\mathrm{a}}$ & $0.314^{\mathrm{a}}$ \\
\hline Logged Area-R (LAr) & $0.491^{\mathrm{a}}$ & $0.016^{\mathrm{a}}$ & $0.103^{\mathrm{a}}$ & $0.102^{\mathrm{a}}$ & $0.271^{\mathrm{a}}$ \\
\hline \multirow[t]{2}{*}{ Logged Area-H (LAh) } & $0.449^{\mathrm{a}}$ & $0.015^{\mathrm{a}}$ & $0.064^{\mathrm{b}}$ & $0.083^{\mathrm{a}}$ & $0.287^{\mathrm{a}}$ \\
\hline & \multicolumn{5}{|c|}{$30-40 \mathrm{~cm}$ depth } \\
\hline Logging Road (LR) & $0.517^{\mathrm{a}}$ & $0.020^{\mathrm{a}}$ & $0.060^{\mathrm{a}}$ & $0.095^{\mathrm{a}}$ & $0.342^{\mathrm{a}}$ \\
\hline Log Landing (LL) & $0.485^{\mathrm{a}}$ & $0.014^{\mathrm{a}}$ & $0.053^{\mathrm{a}}$ & $0.110^{\mathrm{a}}$ & $0.307^{\mathrm{ab}}$ \\
\hline Logged Area-R (LAr) & $0.480^{\mathrm{a}}$ & $0.024^{\mathrm{a}}$ & $0.076^{\mathrm{a}}$ & $0.109^{\mathrm{a}}$ & $0.272^{\mathrm{b}}$ \\
\hline Logged Area-H (LAh) & $0.459^{\mathrm{a}}$ & $0.014^{\mathrm{a}}$ & $0.050^{\mathrm{a}}$ & $0.117^{\mathrm{a}}$ & $0.278^{\mathrm{b}}$ \\
\hline \multicolumn{6}{|l|}{ Treatment mean } \\
\hline Logging Road (LR) & 0.466 & 0.015 & 0.063 & 0.112 & 0.275 \\
\hline Log Landing (LL) & 0.470 & 0.016 & 0.065 & 0.118 & 0.271 \\
\hline Logged Area-R (LAr) & 0.520 & 0.026 & 0.119 & 0.107 & 0.268 \\
\hline Logged Area-H (LAh) & 0.494 & 0.019 & 0.078 & 0.116 & 0.281 \\
\hline \multicolumn{6}{|l|}{ Depth mean } \\
\hline $0-10 \mathrm{~cm}$ & 0.530 & 0.024 & 0.110 & 0.133 & 0.263 \\
\hline $10-20 \mathrm{~cm}$ & 0.464 & 0.014 & 0.087 & 0.127 & 0.236 \\
\hline $20-30 \mathrm{~cm}$ & 0.470 & 0.019 & 0.069 & 0.085 & 0.297 \\
\hline $30-40 \mathrm{~cm}$ & 0.485 & 0.018 & 0.060 & 0.108 & 0.300 \\
\hline \multicolumn{6}{|c|}{ Analysis of variance $\mathrm{P}>\mathrm{F}$} \\
\hline Treatment & 0.073 & 0.090 & $<0.010$ & 0.818 & 0.901 \\
\hline Compacted vs. $\mathrm{NC}^{\dagger}$ & 0.020 & 0.036 & $<0.010$ & 0.686 & 0.931 \\
\hline LAr vs. LAh & 0.209 & 0.128 & $<0.010$ & 0.491 & 0.496 \\
\hline LR vs. LL & 0.846 & 0.884 & 0.855 & 0.638 & 0.817 \\
\hline Depth & $<0.010$ & 0.180 & $<0.010$ & $<0.010$ & $<0.010$ \\
\hline Treatment by Depth & $<0.010$ & 0.084 & $<0.010$ & $<0.010$ & $<0.010$ \\
\hline
\end{tabular}

${ }^{\dagger}$ Compacted included LR and LL treatments; NC referred to non-compacted which included LAr and LAh treatments. 

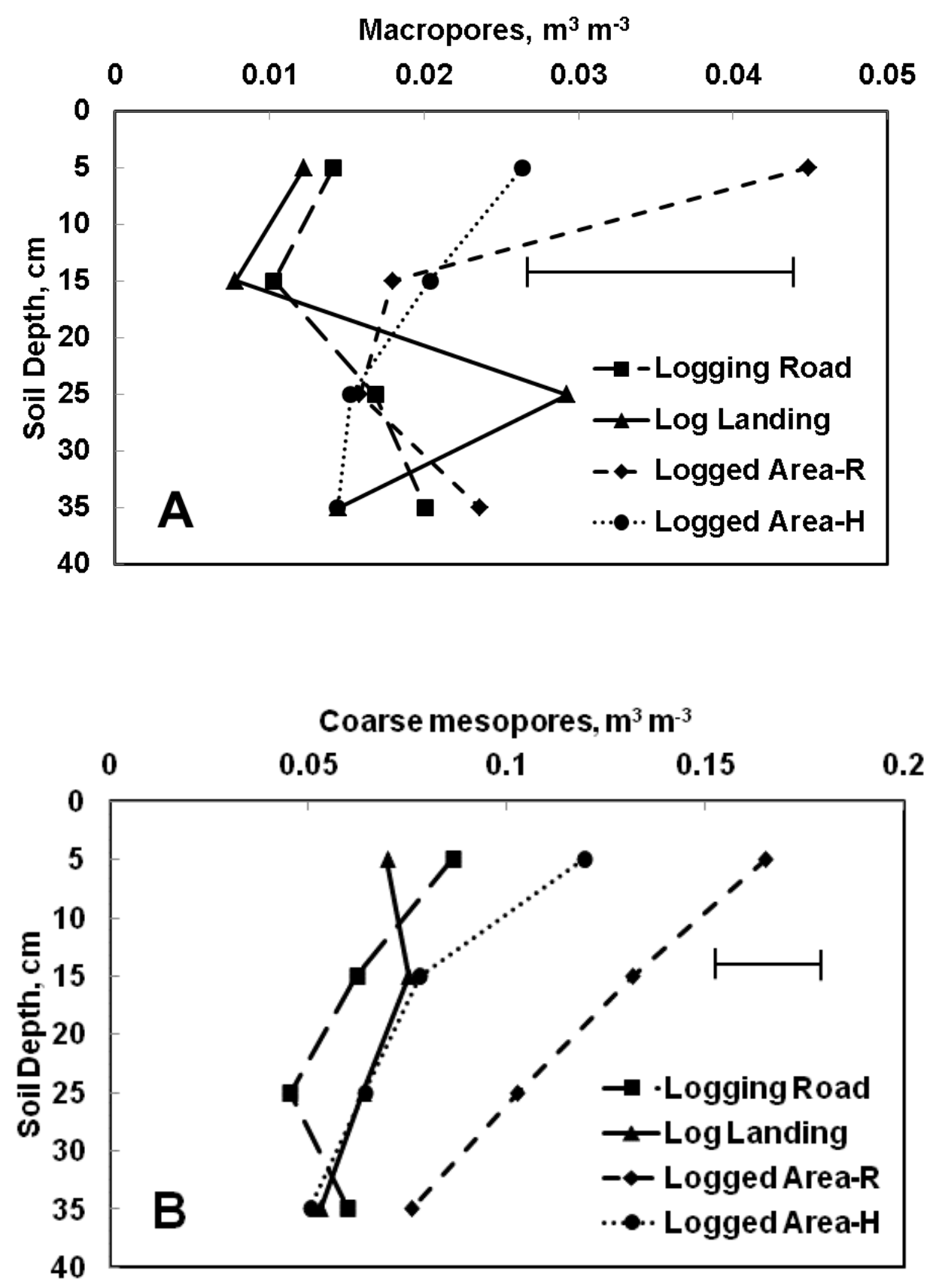

Figure 3.2. Effects of logging treatments and soil depth on pore-size classes of A) macropores (>1000 $\mu \mathrm{m}$ diam.), B) coarse mesopores (60-1000 $\mu \mathrm{m}$ diam.), C) fine mesopores (10 to $60 \mu \mathrm{m}$ diam.), and D) micropores (<10 $\mu \mathrm{m}$ diam.). Bars indicate LSD (0.05) values and are presented for pore-size classes with significant differences among treatments. 


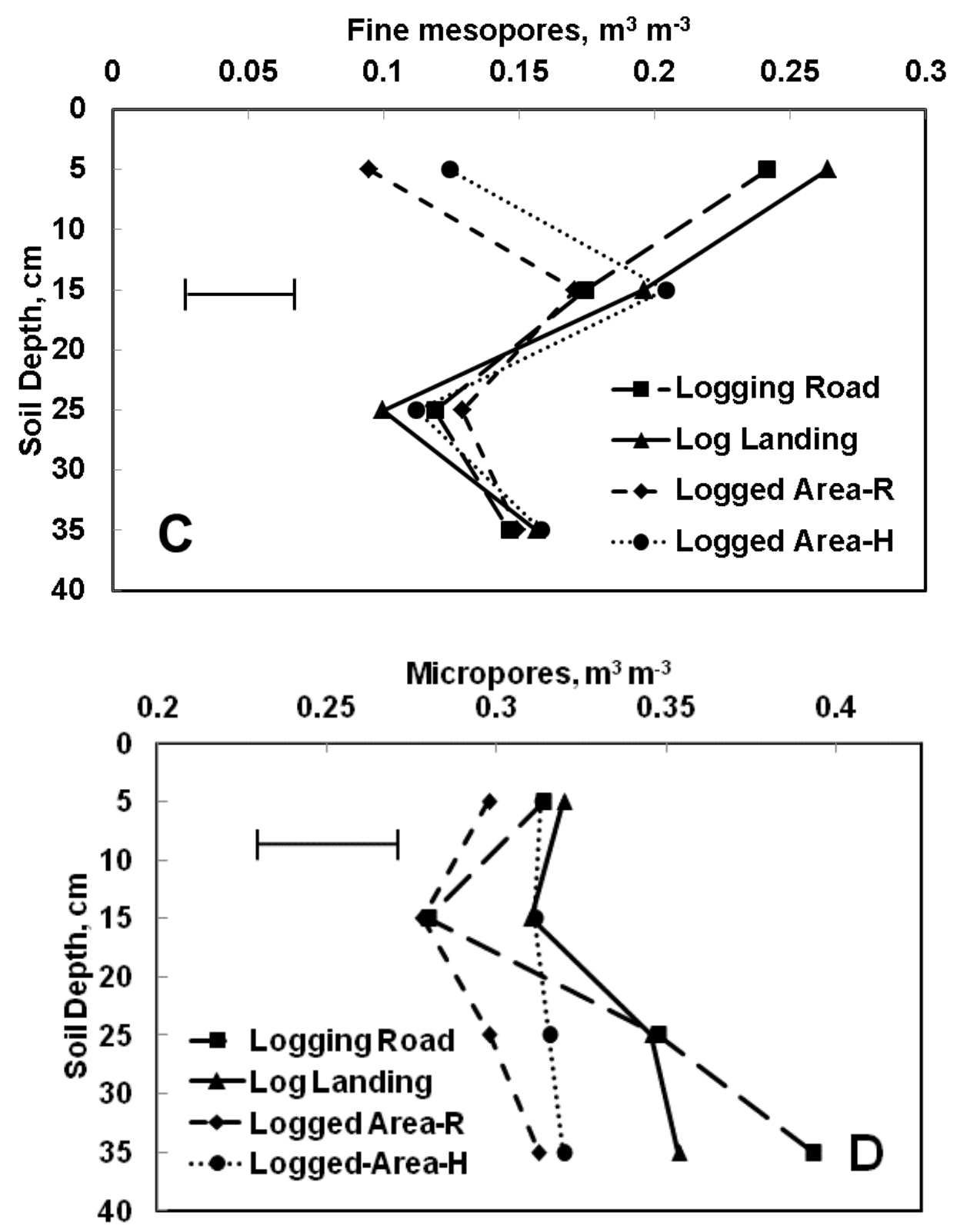

Figure 3.2 (cont.). Effects of logging treatments and soil depth on pore-size classes of A) macropores (>1000 $\mu \mathrm{m}$ diam.), B) coarse mesopores $(60-1000 \mu \mathrm{m}$ diam.), C) fine mesopores (10 to $60 \mu \mathrm{m}$ diam.), and $\mathrm{D})$ micropores ( $<10 \mu \mathrm{m}$ diam.). Bars indicate LSD (0.05) values and are presented for pore-size classes with significant differences among treatments. 
Porosity means for logging treatment and soil depth combinations for the study are presented in Table 3.3. There were significant differences among treatments for total porosity for the upper two depths (Table 3.3). Total porosity is decreasing between the first and second depths then increasing for the third and fourth depths (Table 3.3). Total porosity for the logged area treatments was significantly $(\mathrm{P}<0.01)$ greater than for the logging road and $\log$ landing treatments for the first depth. There was greater total porosity in the logged area recent treatments compared to the logging road and log landing treatment for second soil depth. Differences among treatments for coarse mesoporosity also existed (Fig. 3.2B). Coarse mesoporosity was greater in the logged area treatments compared to the logging road and log landing treatments for the first soil depth. The logged area-recent treatment had greater coarse mesoporosity compared to the logging road and log landing treatments for all soil depths except the $30-40 \mathrm{~cm}$ depth (Fig. 3.2B). Fine mesoporosity was greater in the logging road and log landing treatments compared to the logged area treatments for the $0-10 \mathrm{~cm}$ depth (Fig. 3.2C). Microporosity was greater in the logging road treatment compared to the logged area treatments for the $30-40 \mathrm{~cm}$ soil depth (Fig. 3.2D).

Jansson and Johansson (1998) studying silt loam soils found that harvesting traffic caused pores $>60 \mu \mathrm{m}$ to decrease whereas the smaller pores increased following harvest activities. Micropores may be unaffected and soil porosity changes may be confined to the larger pores in the profile during logging activities (Startsev and McNabb, 2001). Additionally, vegetative growth following logging activities may have a significant effect on porosity at the upper soil depths. Significant differences in coarse mesoporosity were 
found for the first three depths studied between the logged areas and logging road and log landing treatments in the current study.

\section{$\underline{\text { Bulk Density }}$}

The analysis of variance for soil bulk density is presented in Table 3.4. Significant differences $(\mathrm{P}<0.05)$ occurred among logging treatments and soil depths, and for treatment by depth interactions. There were significantly lower bulk density values for the logged area treatments compared to the logging road and log landing treatments as shown in the 'compacted vs. non-compacted' contrast. Bulk density increased in the second and third depths relative to the first depth. The lowest bulk density was found in the first depth as expected due to vegetative regrowth and freeze-thaw cycles.

Bulk density means for logging treatment and soil depth combinations are presented in Table 3.4. Bulk density was significantly lower $(\mathrm{P}<0.01)$ for the logged area treatments compared to the logging road and log landing treatments for the first and second depths (Fig. 3.3A). Bulk density values in the logged area- recent treatment were found to be similar to values measured by Mudgal et al. (2010) in a managed prairie claypan soil in central Missouri which has not been subjected to much equipment traffic. There were no significant differences among treatments for the lower two soil depths.

Page-Dumroese et al. (2006) found soil bulk density increases were noticeable to a depth of $30 \mathrm{~cm}$. This agrees with our results where at the deeper depths there were no significant differences across treatments but at the upper depths there were large differences. The top $10 \mathrm{~cm}$ had significantly lower bulk density values due to the logged area treatments. 


\section{Saturated Hydraulic Conductivity}

The analysis of variance of saturated hydraulic conductivity $\left(\mathrm{K}_{\text {Sat }}\right)$ in soil core samples is presented in Table 3.4. There were significant differences in $\mathrm{K}_{\text {Sat }}$ among treatments, soil depths, and treatment by depth interactions.

$\mathrm{K}_{\text {Sat }}$ was significantly higher $(\mathrm{P}<0.01)$ for the logged area treatments compared to the logging road and log landing treatments as indicated by 'compacted vs. non-compacted' contrast (Table 3.4). The $\mathrm{K}_{\text {Sat }}$ for the logged area treatments was more than thirty-three times higher compared to the logging road and log landing treatments for the first depth. $\mathrm{K}_{\text {Sat }}$ decreased from the first depth to the second due to an increase in bulk density. A study by Williamson and Neilsen (2000) also showed a pattern of decreasing $\mathrm{K}_{\text {sat }}$ with increasing compaction, although there was no overall relationship with bulk density. The lowest $\mathrm{K}_{\text {Sat }}$ values were measured in the fourth depth due to the higher concentration of smectitic clay in this horizon. 
Table 3.4. Means of $\mathrm{K}_{\text {Sat }}$ and arithmetic means of bulk density as affected by buffer treatments and soil depth.

\begin{tabular}{|c|c|c|}
\hline \multirow[t]{2}{*}{ Treatment } & $\mathrm{K}_{\mathrm{Sat}}$ & \multirow{2}{*}{$\begin{array}{l}\text { Bulk density } \\
-----\mathrm{g} \mathrm{cm}^{-3} \text {------ }\end{array}$} \\
\hline & -------------------- $\mathrm{mm} \mathrm{h}^{-1}$----------------- & \\
\hline \multicolumn{3}{|c|}{$\underline{0-10 \mathrm{~cm} \text { depth }}$} \\
\hline Logging Road (LR) & $.274^{\mathrm{c}}$ & $1.388^{\mathrm{a}}$ \\
\hline Log Landing (LL) & $.919^{c}$ & $1.426^{\mathrm{a}}$ \\
\hline Logged Area-R (LAr) & $28.8^{\mathrm{a}}$ & $0.987^{\mathrm{b}}$ \\
\hline Logged Area-R (LAh) & $10.7^{b}$ & $1.010^{\mathrm{b}}$ \\
\hline \multicolumn{3}{|c|}{$10-20 \mathrm{~cm}$ depth } \\
\hline Logging Road (LR) & $.330^{\mathrm{a}}$ & $1.578^{\mathrm{a}}$ \\
\hline Log Landing (LL) & $1.00^{\mathrm{a}}$ & $1.430^{\mathrm{b}}$ \\
\hline Logged Area-R (LAr) & $3.21^{\mathrm{a}}$ & $1.211^{\mathrm{c}}$ \\
\hline Logged Area-R (LAh) & $2.46^{\mathrm{a}}$ & $1.322^{\mathrm{c}}$ \\
\hline \multicolumn{3}{|c|}{$20-30 \mathrm{~cm}$ depth } \\
\hline Logging Road (LR) & $0.098^{\mathrm{a}}$ & $1.416^{\mathrm{a}}$ \\
\hline Log Landing (LL) & $0.428^{\mathrm{a}}$ & $1.389^{\mathrm{a}}$ \\
\hline Logged Area-R (LAr) & $3.82^{\mathrm{a}}$ & $1.279^{\mathrm{b}}$ \\
\hline Logged Area-R (LAh) & $0.861^{\mathrm{a}}$ & $1.426^{\mathrm{a}}$ \\
\hline \multicolumn{3}{|c|}{$\underline{30-40 \mathrm{~cm} \text { depth }}$} \\
\hline Logging Road (LR) & $0.134^{\mathrm{a}}$ & $1.290^{\mathrm{a}}$ \\
\hline Log Landing (LL) & $0.0642^{\mathrm{a}}$ & $1.368^{\mathrm{a}}$ \\
\hline Logged Area-R (LAr) & $1.92^{\mathrm{a}}$ & $1.355^{\mathrm{a}}$ \\
\hline Logged Area-R (LAh) & $0.829^{\mathrm{a}}$ & $1.396^{\mathrm{a}}$ \\
\hline \multicolumn{3}{|l|}{ Treatment mean } \\
\hline Logging Road (LR) & 0.209 & 1.418 \\
\hline Log Landing (LL) & 0.604 & 1.403 \\
\hline Logged Area-R (LAr) & 9.442 & 1.208 \\
\hline Logged Area-R (LAh) & 3.710 & 1.289 \\
\hline \multicolumn{3}{|l|}{ Depth mean } \\
\hline $0-10 \mathrm{~cm}$ & 10.174 & 1.203 \\
\hline $10-20 \mathrm{~cm}$ & 1.752 & 1.385 \\
\hline $20-30 \mathrm{~cm}$ & 1.301 & 1.378 \\
\hline $30-40 \mathrm{~cm}$ & 0.737 & 1.352 \\
\hline \multicolumn{3}{|c|}{ Analysis of variance $\mathrm{P}>\mathrm{F}$} \\
\hline Treatment & $<0.01$ & 0.011 \\
\hline Compacted vs. $\mathrm{NC}^{\dagger}$ & $<0.01$ & $<0.01$ \\
\hline LAr vs. LAh & 0.020 & 0.170 \\
\hline LR vs. LL & 0.851 & 0.792 \\
\hline Depth & $<0.01$ & $<0.01$ \\
\hline Treatment by Depth & $<0.01$ & $<0.01$ \\
\hline
\end{tabular}

${ }^{\dagger}$ Compacted included LR and LL treatments; NC referred to non-compacted which included LAr and LAh treatments. 

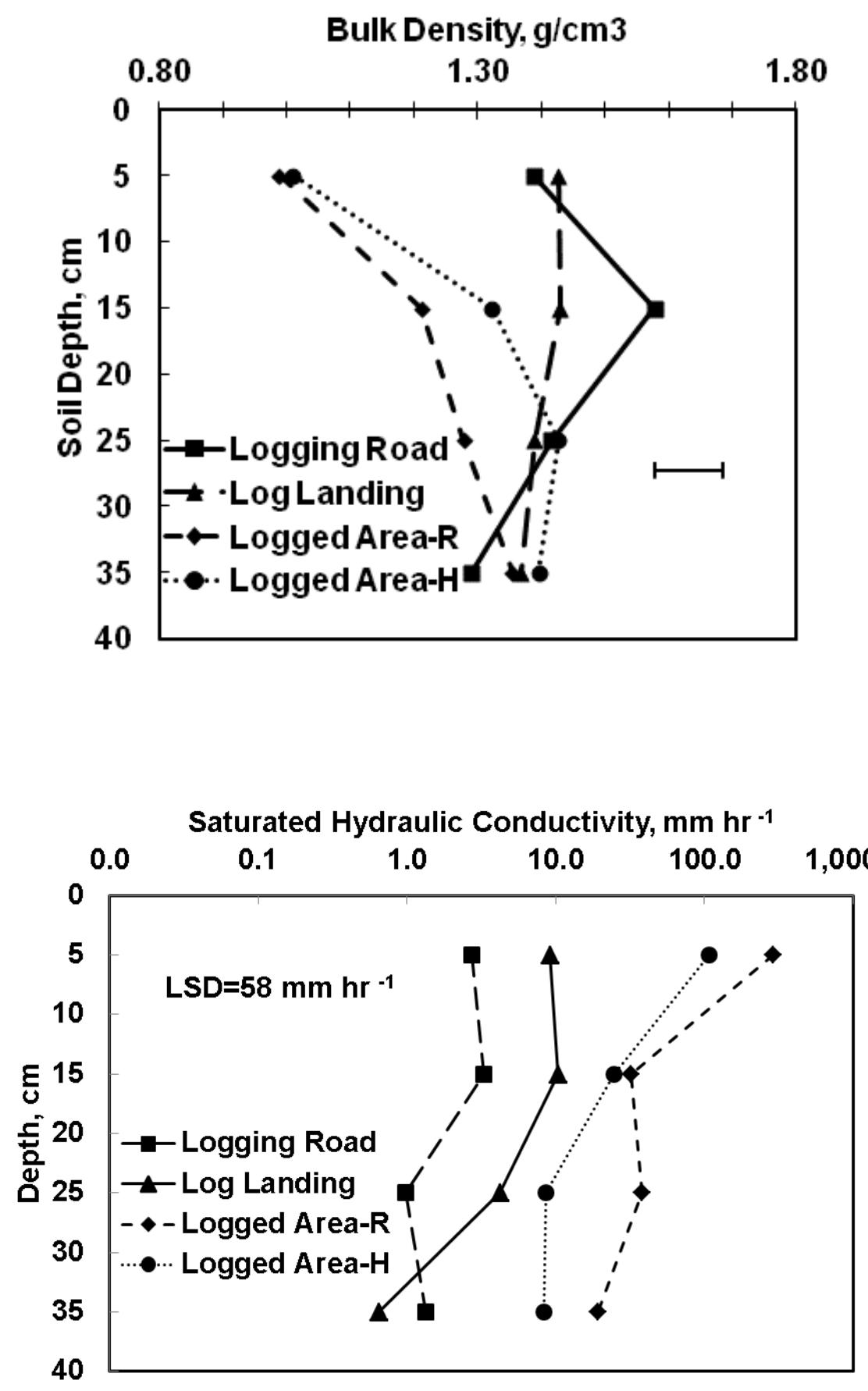

Figure 3.3. Effects of logging treatments and soil depth on A) bulk density and B) saturated hydraulic conductivity $\left(\mathrm{K}_{\mathrm{Sat}}\right)$. The bar indicates the $\operatorname{LSD}(0.05)$ value for bulk density (A) and the LSD (0.05) value for $\mathrm{K}_{\text {Sat }}$ is listed on the graph (B) due to the log scale. 


\section{SUMMARY}

This study was conducted to evaluate the effects of different levels of timber harvest treatments on soil hydraulic properties. Soil water retention, pore-size distribution, bulk density, and saturated hydraulic conductivity were compared for four treatments at four soil depths. The four treatments were logging load, log landing, logged area-recent, and logged area-historic.

The logging road and log landing treatments had significantly lower water content than the logged area treatments at 0 and $-0.4 \mathrm{kPa}$ soil water pressure. These differences were attributed to less reduction in porosity for the logged area treatments. The logged area-recent $(0.520,0.145)$ and the logged area-historic $(0.494,0.097)$ treatments had significantly greater total porosity, and combined macroporosity and coarse mesoporosity (pores $>1000 \mu \mathrm{m}$ diam. and $60-1000 \mu \mathrm{m}$ diam.) than the logging road $(0.466,0.078)$ and $\log$ landing $(0.470,0.081)$ treatments. Logged area treatments $\left(1.25 \mathrm{~g} \mathrm{~cm}^{-3}\right)$ also had significantly lower bulk density values compared to logging road and log landing areas $\left(1.41 \mathrm{~g} \mathrm{~cm}^{-3}\right)$. Significant differences among treatments existed for the two first sampling depths but not the lower two depths. $\mathrm{K}_{\text {Sat }}$ values for the logged area treatments were significantly higher than those of the other two treatments for the first sampling depth. Values for $\mathrm{K}_{\mathrm{Sat}}$ in the surface soil were 33 times greater for the logged areas compared to the logging road and log landing areas.

Soil hydraulic properties which included soil hydraulic conductivity, water retention and pore size distributions were significantly affected by forest harvesting treatments. From this study, the methods used in logged areas appear to have caused less change in soil physical and hydraulic properties; however, significant changes occurred 
with these properties for logging roads and the log landing area. Efforts to reduce compaction should be concentrated in areas of logging roads and log landing areas. 


\section{REFERENCES}

Beckett, P.H.T., Webster, R. (1971): Soil variability: a review. Soils and Fertilisers, 34(4): 1-15.

Blanco-Canqui, H., Gantzer, C. J., Anderson, S. H., \& Alberts, E. E. (2004). DIVISION S-6-SOIL \& WATER MANAGEMENT \& CONSERVATION Tillage and Crop Influences on Physical Properties for an Epiaqualf. Soil Sci. Soc. of Am. J, 68, 567576.

Block, R.K., C. J. Van Rees, and D. J. Pennock. 2002. Quantifying Harvesting Impacts using Soil Compaction and Disturbance Regimes at a Landscape Scale. Soil Sci. Soc. Am. J. 66: 1669-1676.

Braunack, M.V., and B.G. Williams. 1993. "The effect of initial soil water content and vegetative cover on surface soil disturbance by tracked vehicles." Journal of Terramechanics 30:299-311.

Blyth, J.F. and MacLeod, D.A. 1978 The significance of soil variability for forest soil studies in north-east Scotland. J. Soil Sci. 29, 419-430.

Courtin, P., Feller, M.C. \& Klinka, K. (1983) Lateral variability in some properties of disturbed forest soils in southwestern British Columbia. Canadian Journal of Soil Science, 63, 529-539.

Dane, J. H., and G. C. Topp (Eds.) (2002), Methods of Soil Analysis, part 1, Physical Methods, 3rd ed., Soil Sci. Soc. of Am., Madison, Wis. 
Deuchars, S.A., Townend, J., Aitkenhead, M.J., FitzPatrick, E.A., 1999. Changes in soil structure and hydraulic properties in regenerating rain forest. Soil Use Manag. 15, $183-187$.

Froehlich, H. A., Miles, D. W. R., Robbins, R. W., 1985: Soil bulk density recovery on compacted skid trails in central Idaho. Soil Science Society of America Journal 49(4): 1015-1017.

Guinan, P. Golden Gate Weather Services. http://ggweather.com/normals/MO.html, 2013. Conducted by University of Missouri, Soils, Environmental and Atmospheric Sciences Department. Columbia, MO, 2013-06-03.

Hillel, D., Warrick, A. W., Baker, R. S., \& Rosenzweig, C. (1998). Environmental soil physics. San Diego, CA: Academic Press.

Jansson, K. J., and J. Johansson. "Soil Changes after Traffic with a Tracked and a Wheeled Forest Machine: a Case Study on a Silt Loam in Sweden.” Forestry 71, no. 1 (1998): 57-66.

Kingsley, Neal P. and Jay R. Law. 1991. Timber Resource of the Mark Twain National Forest. Resource Bulletin NC-129, St. Paul, MN: USDA, Forest Service, North Central Forest Experiment Station, 31 p.

Liechty, H.O., Sawyer, V.L., Shelton, M.G., 2002. Alteration of nutrient status by manipulation of composition and density in a shortleaf pine-hardwood stand. In: Outcalt, K.W. (Ed.), Proceedings of the Eleventh Biennial Southern Silviculture Research Conference, Knoxville, TN, 20-22 March 2001. USDA For. Serv. Gen. Tech. Re SRS-GT-48, pp. 10-15. 
Miller, R.E., W. Scott and J.W. Hazard.1996. Soil compaction and conifer growth after tractor yarding at three coastal Washington locations. Can. J. For. Res. 26:225-236.

Mudgal, A., S.H. Anderson, C. Baffaut, N.R. Kitchen, and E.J. Sadler. 2010. Effects of long-term soil and crop management on soil hydraulic properties for claypan soils. Journal Soil Water Conservation 65: 393-403.

Page-Dumroese, D., M. Jurgensen, A. Tiarks, F. Sanchez, R. Fleming, M. Kranabetter, R. Powers, F. Ponder, JR., D. Stone, J. Elioff, and A. Scott. 2006. Soil physical property changes on the North American Long-Term Soil Productivity (LTSP) study sites: 1 and 5 years after treatment. Can. J. For. Res. 36:551-564.

Powers, R. F.; D. H. Alban; R.E. Miller; A. E. Tiarks; C. G. Wells; P. E. Avers; R. G. Cline; N. S. Loftus, Jr.; and R. O. Fitzgerald. 1990. Sustaining productivity in North American forests: problems and prospects. In Gessel, S. P.; Lacate, D. S.; Weetman, G. F.; and Powers, R. F., eds. Proceedings of the seventh North American forest soils conference; 1988 July 24-28; Vancouver, British Columbia. Vancouver, British Columbia. University of British Columbia: p 49-79.

Sands, R., Greacen, E.L., and Gerard, C.J. 1979. Compaction of sandy soils in radiata pine forests: I. A penetrometer study. Aust. J. Soil Res. 17: 101-113.

SAS Institute, 1989. SAS Language and Procedures: Usage, 1st ed. SAS Institute Inc., Cary, NC.

Seobi, T., S.H. Anderson, R.P. Udawatta, and C.J. Gantzer. 2005. Influence of grass and agroforestry buffer strips on soil hydraulic properties for an Albaqualf. Soil Sci. Soc. Am. J. 69:893-901. 
Siegel-Issem, C.M.; J. A. Burger; R. F. Powers; F. Ponder; and S. C. Patterson. 2005. Seedling Root Growth as a Function of Soil Density and Water Content. Soil Science Society of America Journal. 69: 215-226.

Soane, B., 1990. The role of organic matter in soil compactibility: A review of some practical aspects. Soil \& Tillage Research, 16, 179-201.

Startsev, A.D., McNabb, D.H., 2001. Skidder traffic effects on water retention, pore-size distribution, and Van Genuchten parameters of boreal forest soils. Soil Sci. Soc. Am. J. 65 (1), 224-231.

Tiarks, A. E. and J.D. Haywood. 1996. Site preparation and fertilization effects on growth of slash pine for two rotations. Soil Science Society of America Journal 60:1654-1663.

U.S. Department of Agriculture [USDA], Forest Service. 2004. Houston/Rolla/Cedar Creek Ranger District, Middle River II, Environmental Assessment. Callaway County, MO: Mark Twain National Forest.

United States Department of Agriculture [USDA], Soil Conservation Service. 1992. Soil survey of Callaway County, Missouri

Williamson, J.R., Neilsen, W.A., 2000. The influence of forest site on rate and extent of soil compaction and profile disturbance of skid trails during ground-based harvesting. Can. J. For. Res. 30, 1196-1205. 


\section{CHAPTER 4}

\section{CONCLUSIONS}

A study was conducted to evaluate different levels of selected timber harvest treatments on soil hydraulic properties. Maintaining good values of soil hydraulic properties is critical for forest management to improve tree production and water conservation in forested watersheds. The properties for this study included soil water retention, pore-size distribution, bulk density, and saturated hydraulic conductivity. Logging road, log landing, logged area-recent, and logged area-historic were the four treatments.

The conclusions from this study include the following:

1. The logging road and log landing treatments had significantly lower water content than the logged area treatments at 0 and $-0.4 \mathrm{kPa}$ soil water pressure. These differences were attributed to less reduction in porosity for the logged area treatments.

2. The logged area-recent $(0.520,0.145)$ and the logged area-historic $(0.494,0.097)$ treatments had significantly greater total porosity, and combined macroporosity and coarse mesoporosity (pores $>1000 \mu \mathrm{m}$ diam. and $60-1000 \mu \mathrm{m}$ diam.) than the logging road $(0.466,0.078)$ and log landing $(0.470,0.081)$ treatments.

3. Logged area treatments $\left(1.25 \mathrm{~g} \mathrm{~cm}^{-3}\right)$ also had significantly lower bulk density values compared to logging road and log landing areas $\left(1.41 \mathrm{~g} \mathrm{~cm}^{-3}\right)$. Significant differences among treatments existed for the two first sampling depths but not the lower two depths. 
4. Saturated hydraulic conductivity $\left(\mathrm{K}_{\text {Sat }}\right)$ values for the logged area treatments were significantly higher than those of the other two treatments for the first sampling depth. Values for $\mathrm{K}_{\mathrm{Sat}}$ in the surface soil were 33 times greater for the logged areas compared to the logging road and log landing areas.

Soil hydraulic properties which included soil hydraulic conductivity, water retention and pore size distributions were significantly affected by forest harvesting treatments. From this study, the methods used in logged areas appear to have caused less change in soil physical and hydraulic properties; however, significant changes occurred with these properties for logging roads and the log landing area. Efforts to reduce compaction should be concentrated in areas of logging roads and log landing areas. 


\section{APPENDICES}

\section{APPENDIX A}

Table A. Soil physical and chemical properties of a representative location within one of the Logged Area-recent treatments within the study area (5 to $9 \%$ slope) presented by profile horizon for the observations.

\begin{tabular}{ccccccc}
\hline $\begin{array}{c}\text { Soil } \\
\text { Horizon }\end{array}$ & Observation & $\begin{array}{c}\text { Soil } \\
\text { Depth }\end{array}$ & Clay & Silt & $\begin{array}{c}\text { Organic } \\
\text { Matter }\end{array}$ & $\mathrm{pH}_{\mathrm{w}}$ \\
\hline \multirow{2}{*}{$\mathrm{A}$} & & $\mathrm{cm}$ & $\%$ & $\%$ & $\mathrm{~g} \mathrm{~kg}^{-1}$ & \\
& 1 & $0-10$ & 17.14 & 80.67 & 32.3 & 5.39 \\
$\mathrm{AE}$ & 2 & $0-10$ & 17.21 & 81.07 & 25.2 & 5.02 \\
& 1 & $10-20$ & 13.00 & 85.24 & 9.2 & 4.76 \\
$\mathrm{BE}_{1}$ & 2 & $10-20$ & 16.73 & 81.41 & 9.8 & 4.90 \\
& 1 & $20-30$ & 24.34 & 74.06 & 15.7 & 4.67 \\
$\mathrm{BE}_{2}$ & 2 & $20-30$ & 20.48 & 78.03 & 10.0 & 4.74 \\
& 1 & $30-40$ & 20.45 & 78.25 & 6.1 & 4.55 \\
& 2 & $30-40$ & 27.86 & 70.84 & 0.0 & 4.60 \\
\hline
\end{tabular}




\section{APPENDIX B}

Table B.1. Volumetric water content at $0.0,-0.4,-1.0,-2.5$, and $-5.0 \mathrm{kPa}$ soil water

pressures for Logged Area-Recent (LA-R), Logged Area-Historic (LA-H), Logging

Road (LR), and Log Landing (LL) treatments; $(\mathrm{Tmt}=$ Treatment, $\mathrm{SS}=$ sub-sample).

\begin{tabular}{|c|c|c|c|c|c|c|c|c|}
\hline \multirow[b]{2}{*}{ Tmt } & \multirow[b]{2}{*}{ Depth } & \multirow[b]{2}{*}{ Replicate } & \multicolumn{6}{|c|}{ Soil Water Pressure $(\mathrm{kPa})$} \\
\hline & & & SS & 0.0 & -0.4 & -1.0 & -2.5 & -5.0 \\
\hline \multirow{9}{*}{ LA-R } & $\mathrm{cm}$ & & & & & $\mathrm{n}^{3} \mathrm{~cm}^{-3}$ & & \\
\hline & $0-10$ & 1 & 1 & 0.666 & 0.634 & 0.557 & 0.491 & 0.421 \\
\hline & & & 2 & 0.671 & 0.563 & 0.463 & 0.408 & 0.368 \\
\hline & & 2 & 1 & 0.622 & 0.567 & 0.486 & 0.434 & 0.391 \\
\hline & & & 2 & 0.614 & 0.602 & 0.556 & 0.495 & 0.421 \\
\hline & & 3 & 1 & 0.560 & 0.484 & 0.423 & 0.395 & 0.380 \\
\hline & & & 2 & 0.542 & 0.524 & 0.475 & 0.440 & 0.412 \\
\hline & & 4 & 1 & 0.561 & 0.556 & 0.495 & 0.441 & 0.380 \\
\hline & & & 2 & 0.582 & 0.529 & 0.474 & 0.408 & 0.365 \\
\hline \multirow[t]{8}{*}{ LA-R } & $10-20$ & 1 & 1 & 0.530 & 0.515 & 0.474 & 0.415 & 0.371 \\
\hline & & & 2 & 0.524 & 0.510 & 0.478 & 0.421 & 0.377 \\
\hline & & 2 & 1 & 0.511 & 0.462 & 0.425 & 0.382 & 0.352 \\
\hline & & & 2 & 0.536 & 0.528 & 0.460 & 0.411 & 0.378 \\
\hline & & 3 & 1 & 0.497 & 0.483 & 0.417 & 0.391 & 0.362 \\
\hline & & & 2 & 0.537 & 0.523 & 0.457 & 0.422 & 0.391 \\
\hline & & 4 & 1 & 0.457 & 0.443 & 0.408 & 0.368 & 0.318 \\
\hline & & & 2 & 0.451 & 0.436 & 0.390 & 0.338 & 0.298 \\
\hline \multirow[t]{8}{*}{ LA-R } & $20-30$ & 1 & 1 & 0.484 & 0.480 & 0.449 & 0.410 & 0.371 \\
\hline & & & 2 & 0.565 & 0.557 & 0.499 & 0.437 & 0.388 \\
\hline & & 2 & 1 & 0.535 & 0.515 & 0.494 & 0.422 & 0.379 \\
\hline & & & 2 & 0.516 & 0.506 & 0.489 & 0.431 & 0.388 \\
\hline & & 3 & 1 & 0.478 & 0.461 & 0.449 & 0.420 & 0.397 \\
\hline & & & 2 & 0.434 & 0.434 & 0.422 & 0.406 & 0.402 \\
\hline & & 4 & 1 & 0.447 & 0.432 & 0.389 & 0.348 & 0.325 \\
\hline & & & 2 & 0.469 & 0.417 & 0.397 & 0.345 & 0.331 \\
\hline \multirow[t]{8}{*}{ LA-R } & $30-40$ & 1 & 1 & 0.503 & 0.452 & 0.442 & 0.396 & 0.370 \\
\hline & & & 2 & 0.552 & 0.526 & 0.483 & 0.428 & 0.397 \\
\hline & & 2 & 1 & 0.481 & 0.467 & 0.460 & 0.407 & 0.371 \\
\hline & & & 2 & 0.485 & 0.470 & 0.444 & 0.408 & 0.376 \\
\hline & & 3 & 1 & 0.463 & 0.427 & 0.419 & 0.404 & 0.379 \\
\hline & & & 2 & 0.436 & 0.418 & 0.409 & 0.398 & 0.383 \\
\hline & & 4 & 1 & 0.490 & 0.490 & 0.448 & 0.441 & 0.438 \\
\hline & & & 2 & 0.430 & 0.400 & 0.359 & 0.337 & 0.328 \\
\hline
\end{tabular}


Table B.1 (continued).

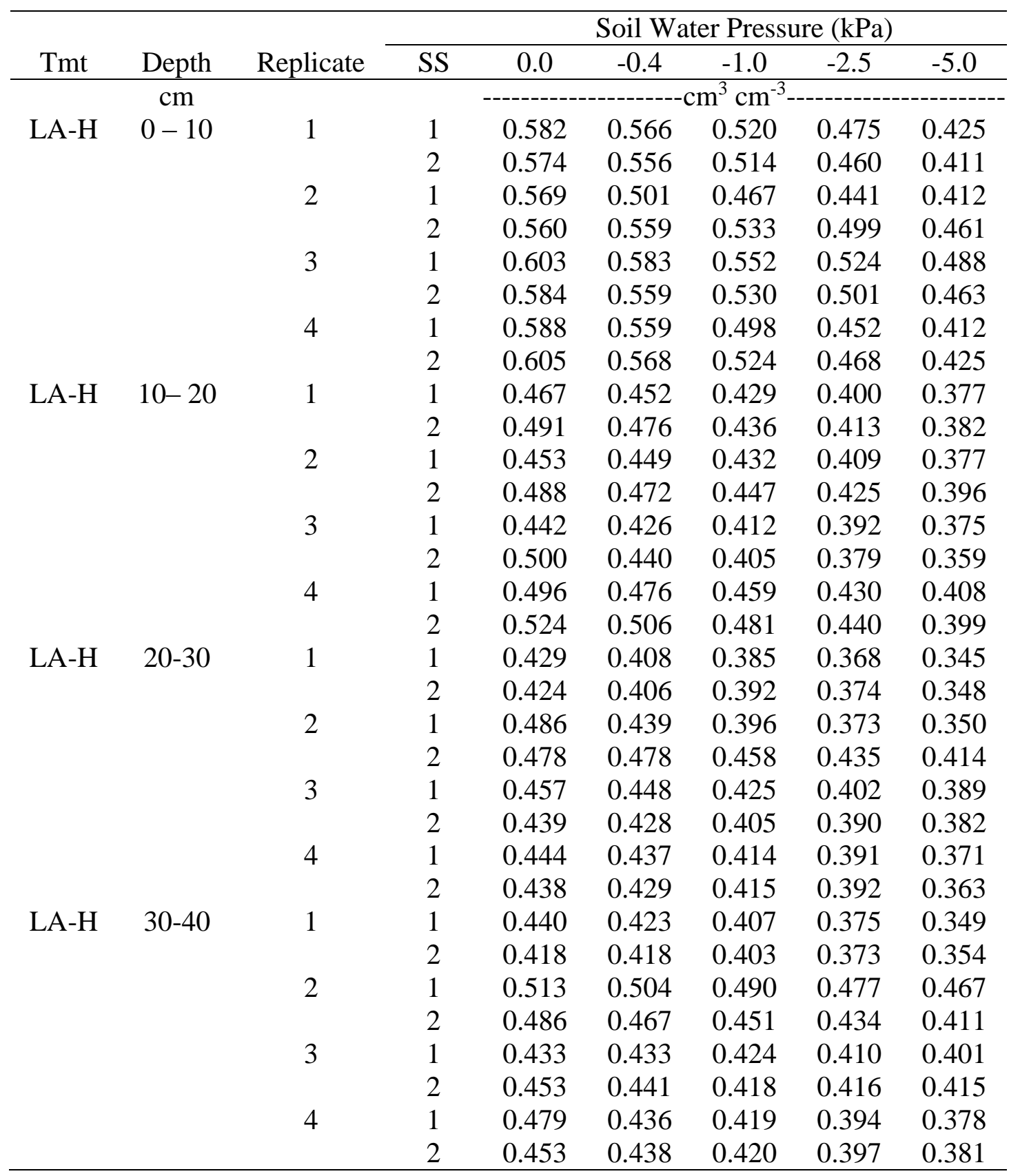


Table B.1 (continued).

\begin{tabular}{|c|c|c|c|c|c|c|c|c|}
\hline \multirow[b]{2}{*}{ Tmt } & \multirow[b]{2}{*}{ Depth } & \multirow[b]{2}{*}{ Replicate } & \multicolumn{6}{|c|}{ Soil Water Pressure $(\mathrm{kPa})$} \\
\hline & & & SS & 0.0 & -0.4 & -1.0 & -2.5 & -5.0 \\
\hline & $\mathrm{cm}$ & & & -------- & ------- & $\mathrm{n}^{3} \mathrm{~cm}^{-3}$ & $\begin{array}{c}---- \\
--1\end{array}$ & - \\
\hline \multirow[t]{8}{*}{ LR } & $0-10$ & 1 & 1 & 0.429 & 0.428 & 0.408 & 0.385 & 0.365 \\
\hline & & & 2 & 0.458 & 0.432 & 0.397 & 0.371 & 0.345 \\
\hline & & 2 & 1 & 0.482 & 0.482 & 0.439 & 0.413 & 0.393 \\
\hline & & & 2 & 0.526 & 0.502 & 0.471 & 0.446 & 0.425 \\
\hline & & 3 & 1 & 0.463 & 0.451 & 0.431 & 0.402 & 0.384 \\
\hline & & & 2 & 0.509 & 0.485 & 0.467 & 0.427 & 0.400 \\
\hline & & 4 & 1 & 0.470 & 0.462 & 0.406 & 0.354 & 0.321 \\
\hline & & & 2 & 0.456 & 0.438 & 0.412 & 0.386 & 0.357 \\
\hline \multirow[t]{8}{*}{ LR } & $10-20$ & 1 & 1 & 0.394 & 0.379 & 0.370 & 0.344 & 0.331 \\
\hline & & & 2 & 0.353 & 0.344 & 0.329 & 0.305 & 0.289 \\
\hline & & 2 & 1 & 0.413 & 0.404 & 0.392 & 0.369 & 0.355 \\
\hline & & & 2 & 0.408 & 0.408 & 0.385 & 0.365 & 0.354 \\
\hline & & 3 & 1 & 0.456 & 0.449 & 0.429 & 0.394 & 0.377 \\
\hline & & & 2 & 0.479 & 0.479 & 0.462 & 0.435 & 0.413 \\
\hline & & 4 & 1 & 0.374 & 0.359 & 0.337 & 0.303 & 0.282 \\
\hline & & & 2 & 0.392 & 0.365 & 0.349 & 0.312 & 0.289 \\
\hline \multirow[t]{8}{*}{ LR } & 20-30 & 1 & 1 & 0.442 & 0.408 & 0.387 & 0.367 & 0.344 \\
\hline & & & 2 & 0.448 & 0.419 & 0.401 & 0.380 & 0.362 \\
\hline & & 2 & 1 & 0.475 & 0.471 & 0.456 & 0.435 & 0.417 \\
\hline & & & 2 & 0.453 & 0.452 & 0.441 & 0.423 & 0.412 \\
\hline & & 3 & 1 & 0.487 & 0.479 & 0.456 & 0.443 & 0.435 \\
\hline & & & 2 & 0.504 & 0.497 & 0.483 & 0.469 & 0.459 \\
\hline & & 4 & 1 & 0.473 & 0.441 & 0.423 & 0.409 & 0.403 \\
\hline & & & 2 & 0.441 & 0.421 & 0.409 & 0.401 & 0.395 \\
\hline \multirow[t]{8}{*}{ LR } & $30-40$ & 1 & 1 & 0.548 & 0.512 & 0.489 & 0.463 & 0.450 \\
\hline & & & 2 & 0.546 & 0.533 & 0.510 & 0.476 & 0.464 \\
\hline & & 2 & 1 & 0.510 & 0.470 & 0.450 & 0.421 & 0.395 \\
\hline & & & 2 & 0.513 & 0.486 & 0.471 & 0.445 & 0.402 \\
\hline & & 3 & 1 & 0.503 & 0.492 & 0.463 & 0.451 & 0.437 \\
\hline & & & 2 & 0.516 & 0.516 & 0.496 & 0.487 & 0.481 \\
\hline & & 4 & 1 & 0.484 & 0.451 & 0.424 & 0.414 & 0.411 \\
\hline & & & 2 & 0.516 & 0.516 & 0.476 & 0.464 & 0.455 \\
\hline
\end{tabular}


Table B.1 (continued).

\begin{tabular}{|c|c|c|c|c|c|c|c|c|}
\hline \multirow[b]{2}{*}{ Tmt } & \multirow[b]{2}{*}{ Depth } & \multirow[b]{2}{*}{ Replicate } & \multicolumn{6}{|c|}{ Soil Water Pressure $(\mathrm{kPa})$} \\
\hline & & & SS & 0.0 & -0.4 & -1.0 & -2.5 & -5.0 \\
\hline & $\mathrm{cm}$ & & & -------- & $\begin{array}{ll}-------1 \\
-1\end{array}$ & $\mathrm{n}^{3} \mathrm{~cm}^{-3}$ & 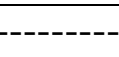 & - \\
\hline \multirow[t]{8}{*}{$\mathrm{LL}$} & $0-10$ & 1 & 1 & 0.405 & 0.402 & 0.373 & 0.365 & 0.350 \\
\hline & & & 2 & 0.469 & 0.418 & 0.385 & 0.365 & 0.344 \\
\hline & & 2 & 1 & 0.432 & 0.418 & 0.398 & 0.378 & 0.375 \\
\hline & & & 2 & 0.439 & 0.437 & 0.413 & 0.391 & 0.372 \\
\hline & & 3 & 1 & 0.450 & 0.450 & 0.429 & 0.406 & 0.383 \\
\hline & & & 2 & 0.466 & 0.466 & 0.434 & 0.417 & 0.394 \\
\hline & & 4 & 1 & 0.518 & 0.505 & 0.479 & 0.448 & 0.419 \\
\hline & & & 2 & 0.517 & 0.501 & 0.455 & 0.427 & 0.401 \\
\hline \multirow[t]{8}{*}{ LL } & $10-20$ & 1 & 1 & 0.414 & 0.409 & 0.387 & 0.360 & 0.341 \\
\hline & & & 2 & 0.426 & 0.426 & 0.405 & 0.387 & 0.372 \\
\hline & & 2 & 1 & 0.485 & 0.485 & 0.462 & 0.436 & 0.420 \\
\hline & & & 2 & 0.469 & 0.457 & 0.448 & 0.417 & 0.394 \\
\hline & & 3 & 1 & 0.433 & 0.427 & 0.418 & 0.395 & 0.378 \\
\hline & & & 2 & 0.519 & 0.496 & 0.461 & 0.414 & 0.391 \\
\hline & & 4 & 1 & 0.430 & 0.424 & 0.398 & 0.363 & 0.334 \\
\hline & & & 2 & 0.491 & 0.482 & 0.433 & 0.401 & 0.374 \\
\hline \multirow[t]{8}{*}{ LL } & 20-30 & 1 & 1 & 0.427 & 0.411 & 0.403 & 0.377 & 0.351 \\
\hline & & & 2 & 0.417 & 0.383 & 0.368 & 0.348 & 0.329 \\
\hline & & 2 & 1 & 0.474 & 0.454 & 0.439 & 0.411 & 0.399 \\
\hline & & & 2 & 0.494 & 0.481 & 0.467 & 0.435 & 0.409 \\
\hline & & 3 & 1 & 0.509 & 0.462 & 0.437 & 0.399 & 0.385 \\
\hline & & & 2 & 0.498 & 0.409 & 0.394 & 0.354 & 0.340 \\
\hline & & 4 & 1 & 0.501 & 0.490 & 0.458 & 0.438 & 0.422 \\
\hline & & & 2 & 0.481 & 0.478 & 0.464 & 0.438 & 0.423 \\
\hline \multirow[t]{8}{*}{ LL } & $30-40$ & 1 & 1 & 0.469 & 0.437 & 0.412 & 0.385 & 0.365 \\
\hline & & & 2 & 0.459 & 0.438 & 0.412 & 0.373 & 0.350 \\
\hline & & 2 & 1 & 0.499 & 0.487 & 0.466 & 0.456 & 0.447 \\
\hline & & & 2 & 0.485 & 0.458 & 0.439 & 0.432 & 0.423 \\
\hline & & 3 & 1 & 0.477 & 0.472 & 0.441 & 0.434 & 0.428 \\
\hline & & & 2 & 0.491 & 0.480 & 0.439 & 0.431 & 0.416 \\
\hline & & 4 & 1 & 0.520 & 0.520 & 0.487 & 0.477 & 0.471 \\
\hline & & & 2 & 0.481 & 0.475 & 0.452 & 0.443 & 0.442 \\
\hline
\end{tabular}


Table B.2. Volumetric water content at $-10,-20,-33,-100$, and $-1500 \mathrm{kPa}$ soil water pressures for Logged Area-Recent (LA-R), Logged Area-Historic (LA-H), Logging Road (LR), and Log Landing (LL) treatments; (SS = sub-sample).

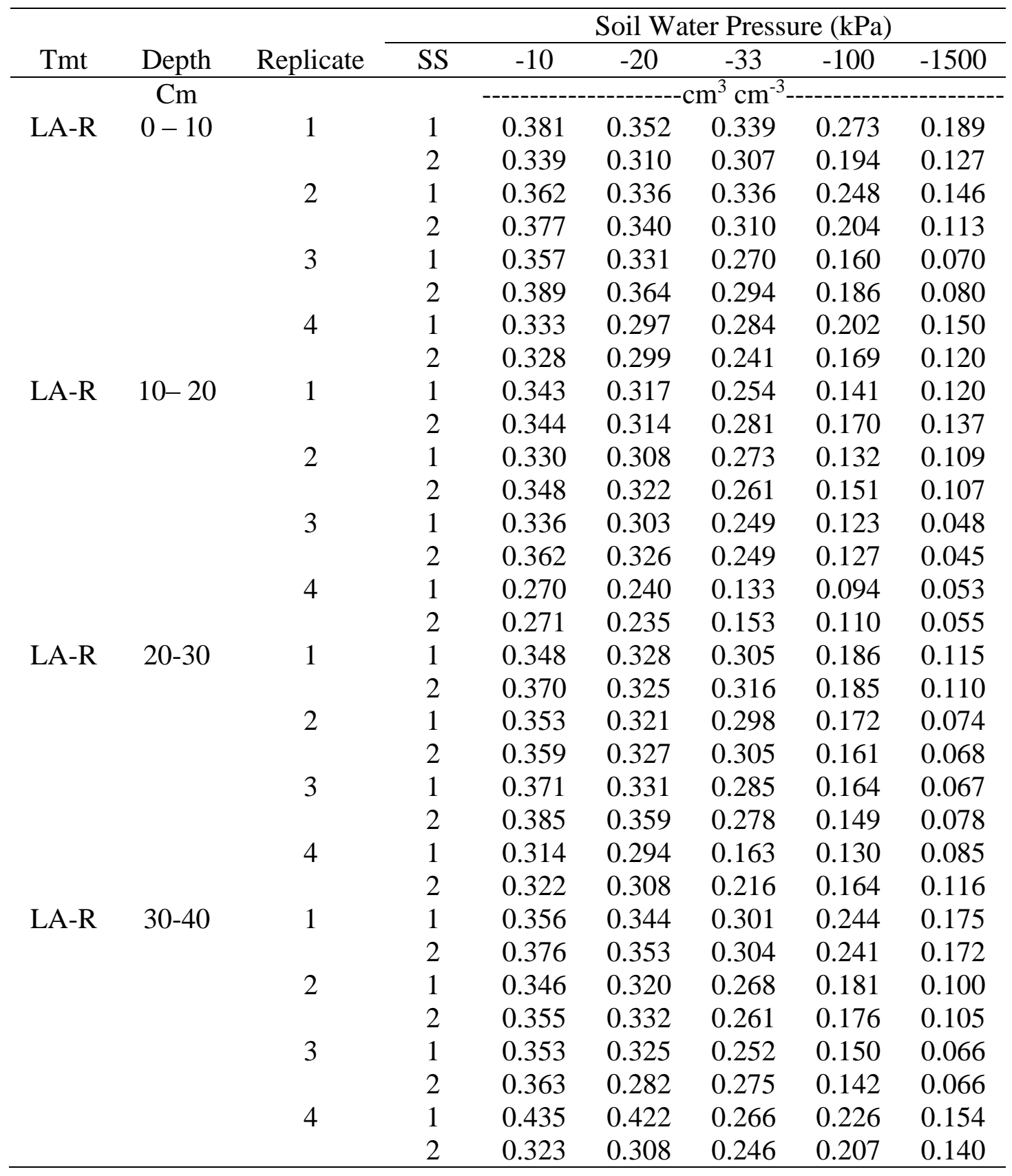


Table B.2 (continued).

\begin{tabular}{|c|c|c|c|c|c|c|c|c|}
\hline \multirow[b]{2}{*}{ Tmt } & \multirow[b]{2}{*}{ Depth } & \multirow[b]{2}{*}{ Replicate } & \multicolumn{6}{|c|}{ Soil Water Pressure $(\mathrm{kPa})$} \\
\hline & & & SS & -10 & -20 & -33 & -100 & -1500 \\
\hline \multirow{9}{*}{ LA-H } & $\mathrm{cm}$ & & & ב----- & 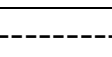 & $\mathrm{n}^{3} \mathrm{~cm}^{-3}$ & & 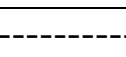 \\
\hline & $0-10$ & 1 & 1 & 0.391 & 0.356 & 0.282 & 0.193 & 0.115 \\
\hline & & & 2 & 0.376 & 0.339 & 0.297 & 0.188 & 0.136 \\
\hline & & 2 & 1 & 0.386 & 0.360 & 0.324 & 0.240 & 0.144 \\
\hline & & & 2 & 0.433 & 0.400 & 0.298 & 0.241 & 0.161 \\
\hline & & 3 & 1 & 0.460 & 0.425 & 0.326 & 0.251 & 0.125 \\
\hline & & & 2 & 0.432 & 0.400 & 0.316 & 0.294 & 0.134 \\
\hline & & 4 & 1 & 0.382 & 0.346 & 0.323 & 0.181 & 0.123 \\
\hline & & & 2 & 0.387 & 0.370 & 0.337 & 0.234 & 0.128 \\
\hline \multirow[t]{8}{*}{ LA-H } & $10-20$ & 1 & 1 & 0.357 & 0.334 & 0.197 & 0.138 & 0.054 \\
\hline & & & 2 & 0.354 & 0.318 & 0.261 & 0.126 & 0.057 \\
\hline & & 2 & 1 & 0.357 & 0.334 & 0.276 & 0.171 & 0.096 \\
\hline & & & 2 & 0.375 & 0.352 & 0.280 & 0.171 & 0.093 \\
\hline & & 3 & 1 & 0.366 & 0.352 & 0.266 & 0.170 & 0.096 \\
\hline & & & 2 & 0.347 & 0.330 & 0.253 & 0.164 & 0.087 \\
\hline & & 4 & 1 & 0.390 & 0.364 & 0.221 & 0.158 & 0.059 \\
\hline & & & 2 & 0.368 & 0.332 & 0.212 & 0.149 & 0.061 \\
\hline \multirow[t]{8}{*}{ LA-H } & 20-30 & 1 & 1 & 0.328 & 0.305 & 0.286 & 0.142 & 0.057 \\
\hline & & & 2 & 0.331 & 0.308 & 0.285 & 0.143 & 0.061 \\
\hline & & 2 & 1 & 0.341 & 0.327 & 0.319 & 0.215 & 0.132 \\
\hline & & & 2 & 0.401 & 0.384 & 0.282 & 0.208 & 0.151 \\
\hline & & 3 & 1 & 0.382 & 0.368 & 0.259 & 0.205 & 0.137 \\
\hline & & & 2 & 0.376 & 0.362 & 0.288 & 0.203 & 0.129 \\
\hline & & 4 & 1 & 0.360 & 0.339 & 0.274 & 0.169 & 0.084 \\
\hline & & & 2 & 0.349 & 0.324 & 0.301 & 0.153 & 0.066 \\
\hline \multirow[t]{8}{*}{ LA-H } & $30-40$ & 1 & 1 & 0.329 & 0.309 & 0.266 & 0.176 & 0.108 \\
\hline & & & 2 & 0.337 & 0.320 & 0.255 & 0.180 & 0.118 \\
\hline & & 2 & 1 & 0.461 & 0.446 & 0.294 & 0.206 & 0.164 \\
\hline & & & 2 & 0.402 & 0.384 & 0.305 & 0.252 & 0.188 \\
\hline & & 3 & 1 & 0.392 & 0.382 & 0.280 & 0.220 & 0.163 \\
\hline & & & 2 & 0.413 & 0.402 & 0.287 & 0.212 & 0.165 \\
\hline & & 4 & 1 & 0.367 & 0.352 & 0.271 & 0.212 & 0.147 \\
\hline & & & 2 & 0.369 & 0.355 & 0.266 & 0.209 & 0.152 \\
\hline
\end{tabular}


Table B.2 (continued).

\begin{tabular}{|c|c|c|c|c|c|c|c|c|}
\hline \multirow[b]{2}{*}{ Tmt } & \multirow[b]{2}{*}{ Depth } & \multirow[b]{2}{*}{ Replicate } & \multicolumn{6}{|c|}{ Soil Water Pressure $(\mathrm{kPa})$} \\
\hline & & & SS & -10 & -20 & -33 & -100 & -1500 \\
\hline \multirow{9}{*}{ LR } & $\mathrm{cm}$ & & & & 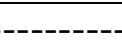 & $\mathrm{m}^{3} \mathrm{~cm}^{-3}$ & & \\
\hline & $0-10$ & 1 & 1 & 0.344 & 0.321 & 0.189 & 0.119 & 0.063 \\
\hline & & & 2 & 0.322 & 0.294 & 0.170 & 0.130 & 0.063 \\
\hline & & 2 & 1 & 0.374 & 0.355 & 0.231 & 0.174 & 0.069 \\
\hline & & & 2 & 0.402 & 0.379 & 0.308 & 0.205 & 0.093 \\
\hline & & 3 & 1 & 0.362 & 0.339 & 0.226 & 0.169 & 0.147 \\
\hline & & & 2 & 0.372 & 0.344 & 0.273 & 0.178 & 0.144 \\
\hline & & 4 & 1 & 0.294 & 0.262 & 0.196 & 0.096 & 0.080 \\
\hline & & & 2 & 0.328 & 0.300 & 0.192 & 0.097 & 0.095 \\
\hline \multirow[t]{8}{*}{ LR } & $10-20$ & 1 & 1 & 0.316 & 0.298 & 0.219 & 0.143 & 0.085 \\
\hline & & & 2 & 0.273 & 0.257 & 0.188 & 0.146 & 0.078 \\
\hline & & 2 & 1 & 0.340 & 0.326 & 0.245 & 0.158 & 0.068 \\
\hline & & & 2 & 0.342 & 0.325 & 0.248 & 0.162 & 0.070 \\
\hline & & 3 & 1 & 0.363 & 0.343 & 0.248 & 0.207 & 0.122 \\
\hline & & & 2 & 0.393 & 0.370 & 0.253 & 0.200 & 0.131 \\
\hline & & 4 & 1 & 0.262 & 0.244 & 0.176 & 0.136 & 0.063 \\
\hline & & & 2 & 0.277 & 0.258 & 0.189 & 0.153 & 0.068 \\
\hline \multirow[t]{8}{*}{ LR } & $20-30$ & 1 & 1 & 0.328 & 0.312 & 0.255 & 0.163 & 0.126 \\
\hline & & & 2 & 0.344 & 0.329 & 0.255 & 0.210 & 0.142 \\
\hline & & 2 & 1 & 0.400 & 0.380 & 0.309 & 0.218 & 0.137 \\
\hline & & & 2 & 0.397 & 0.377 & 0.291 & 0.207 & 0.138 \\
\hline & & 3 & 1 & 0.428 & 0.416 & 0.352 & 0.291 & 0.226 \\
\hline & & & 2 & 0.453 & 0.440 & 0.383 & 0.337 & 0.212 \\
\hline & & 4 & 1 & 0.398 & 0.389 & 0.372 & 0.321 & 0.250 \\
\hline & & & 2 & 0.389 & 0.380 & 0.310 & 0.241 & 0.174 \\
\hline \multirow[t]{8}{*}{ LR } & $30-40$ & 1 & 1 & 0.443 & 0.429 & 0.355 & 0.292 & 0.217 \\
\hline & & & 2 & 0.456 & 0.444 & 0.352 & 0.308 & 0.237 \\
\hline & & 2 & 1 & 0.378 & 0.361 & 0.286 & 0.235 & 0.145 \\
\hline & & & 2 & 0.392 & 0.379 & 0.296 & 0.242 & 0.169 \\
\hline & & 3 & 1 & 0.431 & 0.417 & 0.337 & 0.286 & 0.203 \\
\hline & & & 2 & 0.474 & 0.464 & 0.343 & 0.278 & 0.225 \\
\hline & & 4 & 1 & 0.408 & 0.398 & 0.364 & 0.296 & 0.216 \\
\hline & & & 2 & 0.447 & 0.421 & 0.402 & 0.311 & 0.258 \\
\hline
\end{tabular}


Table B.2 (continued).

\begin{tabular}{|c|c|c|c|c|c|c|c|c|}
\hline \multirow[b]{2}{*}{ Tmt } & \multirow[b]{2}{*}{ Depth } & \multirow[b]{2}{*}{ Replicate } & \multicolumn{6}{|c|}{ Soil Water Pressure $(\mathrm{kPa})$} \\
\hline & & & SS & -10 & -20 & -33 & -100 & -1500 \\
\hline \multirow{9}{*}{ LL } & $\mathrm{cm}$ & & & & 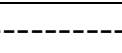 & $\mathrm{m}^{3} \mathrm{~cm}^{-3}$ & & \\
\hline & $0-10$ & 1 & 1 & 0.330 & 0.300 & 0.188 & 0.134 & 0.070 \\
\hline & & & 2 & 0.317 & 0.294 & 0.197 & 0.142 & 0.076 \\
\hline & & 2 & 1 & 0.340 & 0.320 & 0.216 & 0.159 & 0.085 \\
\hline & & & 2 & 0.349 & 0.326 & 0.237 & 0.178 & 0.099 \\
\hline & & 3 & 1 & 0.360 & 0.336 & 0.217 & 0.175 & 0.099 \\
\hline & & & 2 & 0.374 & 0.351 & 0.243 & 0.186 & 0.115 \\
\hline & & 4 & 1 & 0.387 & 0.357 & 0.225 & 0.172 & 0.149 \\
\hline & & & 2 & 0.375 & 0.352 & 0.222 & 0.162 & 0.136 \\
\hline \multirow[t]{8}{*}{ LL } & $10-20$ & 1 & 1 & 0.318 & 0.299 & 0.243 & 0.167 & 0.102 \\
\hline & & & 2 & 0.367 & 0.333 & 0.233 & 0.154 & 0.100 \\
\hline & & 2 & 1 & 0.405 & 0.394 & 0.260 & 0.193 & 0.117 \\
\hline & & & 2 & 0.371 & 0.348 & 0.263 & 0.202 & 0.134 \\
\hline & & 3 & 1 & 0.356 & 0.335 & 0.261 & 0.162 & 0.082 \\
\hline & & & 2 & 0.369 & 0.352 & 0.256 & 0.210 & 0.129 \\
\hline & & 4 & 1 & 0.314 & 0.288 & 0.194 & 0.147 & 0.084 \\
\hline & & & 2 & 0.353 & 0.329 & 0.247 & 0.182 & 0.096 \\
\hline \multirow[t]{8}{*}{ LL } & $20-30$ & 1 & 1 & 0.331 & 0.316 & 0.272 & 0.157 & 0.106 \\
\hline & & & 2 & 0.314 & 0.298 & 0.287 & 0.157 & 0.102 \\
\hline & & 2 & 1 & 0.390 & 0.376 & 0.314 & 0.244 & 0.179 \\
\hline & & & 2 & 0.408 & 0.379 & 0.330 & 0.260 & 0.192 \\
\hline & & 3 & 1 & 0.373 & 0.359 & 0.316 & 0.263 & 0.186 \\
\hline & & & 2 & 0.319 & 0.305 & 0.300 & 0.265 & 0.186 \\
\hline & & 4 & 1 & 0.412 & 0.398 & 0.340 & 0.352 & 0.222 \\
\hline & & & 2 & 0.412 & 0.397 & 0.353 & 0.296 & 0.197 \\
\hline \multirow[t]{8}{*}{ LL } & $30-40$ & 1 & 1 & 0.350 & 0.332 & 0.255 & 0.182 & 0.129 \\
\hline & & & 2 & 0.334 & 0.315 & 0.240 & 0.174 & 0.125 \\
\hline & & 2 & 1 & 0.439 & 0.407 & 0.317 & 0.255 & 0.175 \\
\hline & & & 2 & 0.418 & 0.402 & 0.312 & 0.263 & 0.184 \\
\hline & & 3 & 1 & 0.423 & 0.413 & 0.304 & 0.261 & 0.178 \\
\hline & & & 2 & 0.411 & 0.399 & 0.334 & 0.280 & 0.197 \\
\hline & & 4 & 1 & 0.468 & 0.455 & 0.372 & 0.327 & 0.224 \\
\hline & & & 2 & 0.440 & 0.433 & 0.327 & 0.278 & 0.208 \\
\hline
\end{tabular}




\section{APPENDIX C}

Table C.1. Saturated hydraulic conductivity $\left(\mathrm{K}_{\mathrm{Sat}}\right)$ and bulk density for Logged Area-

Recent, Logged Area-Historic, Logging Road, and Log Landing treatments at four soil depths.

\begin{tabular}{|c|c|c|c|c|c|}
\hline Treatment & Depth & Replicate & $\begin{array}{c}\text { Sub } \\
\text { Sample }\end{array}$ & $\mathrm{K}_{\text {Sat }}$ & $\begin{array}{c}\text { Bulk } \\
\text { Density }\end{array}$ \\
\hline & $\mathrm{cm}$ & & & $\mathrm{cm} \mathrm{h}^{-1}$ & $\mathrm{~g} \mathrm{~cm}^{-3}$ \\
\hline \multirow{8}{*}{ Logged Area-R } & $0-10$ & 1 & 1 & 47.46 & 0.86 \\
\hline & & & 2 & 41.40 & 0.87 \\
\hline & & 2 & 1 & 43.65 & 0.92 \\
\hline & & & 2 & 19.21 & 0.92 \\
\hline & & 3 & 1 & 13.93 & 1.12 \\
\hline & & & 2 & 18.62 & 1.07 \\
\hline & & 4 & 1 & 15.65 & 1.03 \\
\hline & & & 2 & 30.60 & 1.11 \\
\hline \multirow[t]{8}{*}{ Logged Area-R } & $10-20$ & 1 & 1 & 1.19 & 1.19 \\
\hline & & & 2 & 2.84 & 1.10 \\
\hline & & 2 & 1 & 5.23 & 1.16 \\
\hline & & & 2 & 8.40 & 1.08 \\
\hline & & 3 & 1 & 0.35 & 1.17 \\
\hline & & & 2 & 0.63 & 1.24 \\
\hline & & 4 & 1 & 1.18 & 1.34 \\
\hline & & & 2 & 5.88 & 1.41 \\
\hline \multirow[t]{8}{*}{ Logged Area-R } & $20-30$ & 1 & 1 & 5.60 & 1.28 \\
\hline & & & 2 & 18.24 & 1.04 \\
\hline & & 2 & 1 & 2.24 & 1.17 \\
\hline & & & 2 & 1.59 & 1.18 \\
\hline & & 3 & 1 & 0.35 & 1.29 \\
\hline & & & 2 & 0.04 & 1.46 \\
\hline & & 4 & 1 & 2.30 & 1.40 \\
\hline & & & 2 & 0.20 & 1.41 \\
\hline \multirow[t]{8}{*}{ Logged Area-R } & $30-40$ & 1 & 1 & 2.47 & 1.32 \\
\hline & & & 2 & 8.14 & 1.19 \\
\hline & & 2 & 1 & 2.89 & 1.24 \\
\hline & & & 2 & 1.70 & 1.28 \\
\hline & & 3 & 1 & 0.11 & 1.40 \\
\hline & & & 2 & 0.075 & 1.50 \\
\hline & & 4 & 1 & 0.001 & 1.40 \\
\hline & & & 2 & 0.008 & 1.51 \\
\hline
\end{tabular}


Table C.1 (continued).

\begin{tabular}{|c|c|c|c|c|c|}
\hline Treatment & Depth & Replicate & $\begin{array}{c}\text { Sub } \\
\text { Sample }\end{array}$ & $\mathrm{K}_{\text {Sat }}$ & $\begin{array}{c}\text { Bulk } \\
\text { Density }\end{array}$ \\
\hline & $\mathrm{cm}$ & & & $\mathrm{cm} \mathrm{h}^{-1}$ & $\mathrm{~g} \mathrm{~cm}^{-3}$ \\
\hline \multirow[t]{8}{*}{ Logged Area-H } & $0-10$ & 1 & 1 & 9.20 & 1.05 \\
\hline & & & 2 & 5.44 & 0.98 \\
\hline & & 2 & 1 & 49.74 & 1.06 \\
\hline & & & 2 & 0.33 & 1.09 \\
\hline & & 3 & 1 & 2.28 & 0.99 \\
\hline & & & 2 & 1.14 & 1.01 \\
\hline & & 4 & 1 & 5.04 & 1.03 \\
\hline & & & 2 & 12.35 & 0.87 \\
\hline \multirow[t]{8}{*}{ Logged Area-H } & $10-20$ & 1 & 1 & 0.12 & 1.36 \\
\hline & & & 2 & 0.33 & 1.28 \\
\hline & & 2 & 1 & 0.107 & 1.39 \\
\hline & & & 2 & 14.18 & 1.29 \\
\hline & & 3 & 1 & 0.36 & 1.48 \\
\hline & & & 2 & 3.64 & 1.23 \\
\hline & & 4 & 1 & 0.27 & 1.33 \\
\hline & & & 2 & 0.70 & 1.22 \\
\hline \multirow[t]{8}{*}{ Logged Area-H } & $20-30$ & 1 & 1 & 2.20 & 1.51 \\
\hline & & & 2 & 0.60 & 1.44 \\
\hline & & 2 & 1 & 0.136 & 1.29 \\
\hline & & & 2 & 0.24 & 1.32 \\
\hline & & 3 & 1 & 0.187 & 1.44 \\
\hline & & & 2 & 2.63 & 1.49 \\
\hline & & 4 & 1 & 0.23 & 1.46 \\
\hline & & & 2 & 0.75 & 1.46 \\
\hline \multirow[t]{8}{*}{ Logged Area-H } & $30-40$ & 1 & 1 & 0.89 & 1.49 \\
\hline & & & 2 & 0.211 & 1.48 \\
\hline & & 2 & 1 & 0.014 & 1.29 \\
\hline & & & 2 & 0.017 & 1.29 \\
\hline & & 3 & 1 & 0.056 & 1.41 \\
\hline & & & 2 & 0.006 & 1.45 \\
\hline & & 4 & 1 & 5.29 & 1.38 \\
\hline & & & 2 & 0.143 & 1.38 \\
\hline
\end{tabular}


Table C.1 (continued).

\begin{tabular}{|c|c|c|c|c|c|}
\hline Treatment & Depth & Replicate & $\begin{array}{c}\text { Sub } \\
\text { Sample }\end{array}$ & $\mathrm{K}_{\text {Sat }}$ & $\begin{array}{c}\text { Bulk } \\
\text { Density }\end{array}$ \\
\hline & $\mathrm{cm}$ & & & $\mathrm{cm} \mathrm{h}^{-1}$ & $\mathrm{~g} \mathrm{~cm}^{-3}$ \\
\hline \multirow[t]{8}{*}{ Logging Road } & $0-10$ & 1 & 1 & 0.051 & 1.49 \\
\hline & & & 2 & 0.25 & 1.43 \\
\hline & & 2 & 1 & 0.15 & 1.39 \\
\hline & & & 2 & 0.78 & 1.26 \\
\hline & & 3 & 1 & 0.14 & 1.42 \\
\hline & & & 2 & 0.28 & 1.30 \\
\hline & & 4 & 1 & 0.35 & 1.37 \\
\hline & & & 2 & 0.18 & 1.44 \\
\hline \multirow[t]{8}{*}{ Logging Road } & $10-20$ & 1 & 1 & 0.24 & 1.61 \\
\hline & & & 2 & 0.21 & 1.71 \\
\hline & & 2 & 1 & 0.11 & 1.56 \\
\hline & & & 2 & 0.035 & 1.60 \\
\hline & & 3 & 1 & 0.64 & 1.44 \\
\hline & & & 2 & 0.50 & 1.43 \\
\hline & & 4 & 1 & 0.27 & 1.66 \\
\hline & & & 2 & 0.64 & 1.61 \\
\hline \multirow[t]{8}{*}{ Logging Road } & $20-30$ & 1 & 1 & 0.40 & 1.48 \\
\hline & & & 2 & 0.15 & 1.46 \\
\hline & & 2 & 1 & 0.17 & 1.39 \\
\hline & & & 2 & 0.140 & 1.45 \\
\hline & & 3 & 1 & 0.012 & 1.36 \\
\hline & & & 2 & 0.002 & 1.31 \\
\hline & & 4 & 1 & 0.003 & 1.40 \\
\hline & & & 2 & 0.004 & 1.48 \\
\hline \multirow[t]{8}{*}{ Logging Road } & $30-40$ & 1 & 1 & 0.37 & 1.20 \\
\hline & & & 2 & 0.009 & 1.20 \\
\hline & & 2 & 1 & 0.63 & 1.30 \\
\hline & & & 2 & 0.005 & 1.29 \\
\hline & & 3 & 1 & 0.042 & 1.32 \\
\hline & & & 2 & 0.006 & 1.32 \\
\hline & & 4 & 1 & 0.004 & 1.37 \\
\hline & & & 2 & 0.002 & 1.32 \\
\hline
\end{tabular}


Table C.1 (continued).

\begin{tabular}{|c|c|c|c|c|c|}
\hline Treatment & Depth & Replicate & $\begin{array}{c}\text { Sub } \\
\text { Sample }\end{array}$ & $\mathrm{K}_{\text {Sat }}$ & $\begin{array}{c}\text { Bulk } \\
\text { Density }\end{array}$ \\
\hline \multirow{9}{*}{ Log Landing } & $\mathrm{cm}$ & & & $\mathrm{cm} \mathrm{h}^{-1}$ & $\mathrm{~g} \mathrm{~cm}^{-3}$ \\
\hline & $0-10$ & 1 & 1 & 0.91 & 1.58 \\
\hline & & & 2 & 1.83 & 1.41 \\
\hline & & 2 & 1 & 0.022 & 1.50 \\
\hline & & & 2 & 0.231 & 1.49 \\
\hline & & 3 & 1 & 0.41 & 1.46 \\
\hline & & & 2 & 0.28 & 1.41 \\
\hline & & 4 & 1 & 1.72 & 1.28 \\
\hline & & & 2 & 1.96 & 1.28 \\
\hline \multirow{8}{*}{ Log Landing } & $10-20$ & 1 & 1 & 0.18 & 1.55 \\
\hline & & & 2 & 0.104 & 1.54 \\
\hline & & 2 & 1 & 0.01 & 1.36 \\
\hline & & & 2 & 0.53 & 1.41 \\
\hline & & 3 & 1 & 0.13 & 1.50 \\
\hline & & & 2 & 29.48 & 1.22 \\
\hline & & 4 & 1 & 1.13 & 1.51 \\
\hline & & & 2 & 14.31 & 1.35 \\
\hline \multirow[t]{8}{*}{ Log Landing } & $20-30$ & 1 & 1 & 0.79 & 1.52 \\
\hline & & & 2 & 0.17 & 1.54 \\
\hline & & 2 & 1 & 0.045 & 1.39 \\
\hline & & & 2 & 0.003 & 1.34 \\
\hline & & 3 & 1 & 15.93 & 1.30 \\
\hline & & & 2 & 0.17 & 1.33 \\
\hline & & 4 & 1 & 0.41 & 1.32 \\
\hline & & & 2 & 0.17 & 1.37 \\
\hline \multirow[t]{8}{*}{ Log Landing } & $30-40$ & 1 & 1 & 0.12 & 1.41 \\
\hline & & & 2 & 0.33 & 1.43 \\
\hline & & 2 & 1 & 0.001 & 1.33 \\
\hline & & & 2 & 0.002 & 1.37 \\
\hline & & 3 & 1 & 0.027 & 1.39 \\
\hline & & & 2 & 0.025 & 1.35 \\
\hline & & 4 & 1 & 0.003 & 1.28 \\
\hline & & & 2 & 0.003 & 1.38 \\
\hline
\end{tabular}




\section{VITA}

Langston A. Simmons was raised in Fairfield, a western suburb of Birmingham, Alabama. As a child growing up he had a vivid imagination and knew there was a great world outside of his neighborhood and that someday he would be involved in and play a key role within it.

Growing up in the western suburbs of Birmingham, Alabama, his generation of youth was, and youth there today still are, introduced to crime and other detrimental activities frequently and at an early age. The Boy Scouts of America helped Langston to connect with nature and at the same time develop a sound character. His father, as the Scoutmaster, kept him, his two brothers, and many other boys involved and saw to it that many young men reached the highest rank of Eagle Scout. Langston was awarded a United States Department of Agriculture (USDA) / 1890 Land Grant Universities Scholarship to Tennessee State University (TSU) in 2001.

Following graduation from TSU in 2005, he moved to Fulton, MO to work as a Biological Scientist with the USDA Forest Service. Upon moving to Mid-Missouri, Langston soon became comfortable in the community, joining and participating in several local organizations. He served as a mentor to middle school boys in a program called TEAM (Together Everyone Achieves More) Challenge. He was as a trustee at a local church and an active member of the Fulton branch of the National Association for the 
Advancement of Colored People. Additionally, he was the Chapter Advisor for the Lincoln University undergraduate chapter of Iota Phi Theta Fraternity, Inc., of which he is a member. Meanwhile, back in his hometown of Birmingham, AL the times continued to change from his childhood there. Over half of the males who went to high school with him were being killed or sent to jail. When his best friend, Damien Sherrod, from middle school was killed in January of 2009 it hit Langston hard. He decided he needed to make a change to be more of a positive influence on society. It is his belief that everything in life is interconnected in a web. A future with poor soils will cause food and timber shortages which in turn will cause more poverty and more friends being murdered. His friend's death, along with encouragements from his undergraduate professors and his mother among others, persuaded him to further his knowledge in his discipline of soils. 